American Journal of Economics and Business Administration 1 (2) 57-78, 2009

ISSN 1945-5488

(C) 2009 Science Publications

\title{
European Union and a Cost Benefits Analysis for its Members: The Case of Historic Greece
}

\author{
Ioannis N. Kallianiotis \\ Department of Economics and Finance, The Arthur J. Kania School of Management, \\ University of Scranton, Scranton, PA 18510-4602 USA
}

\begin{abstract}
Problem statement: This study tried to determine the cost and benefits of Greece before and after joining the European Union and some of the problems that the current European (and the prospective Euro-Asian) Union has created to all European citizens. Approach: The most severe ones were the social chaos, which was increasing every day, due to the current financial crisis and the worst recession since the great depression of 1929-1930; the economic and political corruption, which were underrated by the officials and the tremendous uncertainty that this artificial and controlled "creature" has generated to its member-nations and their citizens. Results: Europe has a seven thousand years old history, which came from the ancient Hellenic (Greek) civilization and was complemented by Christianity and does not have the right to go backwards. Hellas (Greece) experienced and continues to have many difficulties, conflicts and invasions by barbarians and other neighboring countries. But at the same time, many good periods with tremendous contribution to the global scene are recorded. After WW II, the nation and citizens enjoyed a huge growth, a stable development, a multiple improvement and a preservation of their traditional social values. Lately, the fear from her neighbors and the pressure from her "friends" made Prime Minister, Constantinos Karamanlis, to "throw Greeks in the deep [but not very clean] waters of the European Union". Conclusion: This European integration has destroyed the sovereign nation-states and it is ruling undemocratically an entire continent. Its economic and social policies could not satisfy any welfare functions for the Europeans. Overall, the cost of the European Union exceeds manifold its benefits.
\end{abstract}

Key Words: Economic welfare, economic integration, economic and monetary union, unemployment, public policy

\section{INTRODUCTION}

The intention in this study is to provide a very short outline of the economic history lying behind Greece before and after her joint to European Union (EU), a cost benefit analysis, her interdependence with EU and the effectiveness of her lost public policies. Europe and "European Union" is nowadays a very political word and we will try to see what they have in common. The answer is that Europe has been different things at different times and has caused similar problems all the times. The goal of the study is to present a swift historical journey of Greece and to analyze the severe changes that have taken place in this EU country-member after the 1957 Common Market idea, the 1981 entrance of Greece to the EC, the 1992 integration and the 2002 imposition of Euro and abandonment of drachma. Of course, history now gets less attention among economists and at Business Schools as it was once the case and that makes current economies more vulnerable than in the past. Some important topics have been excluded from this study because there is not enough room for the entire Hellenic history. Human beings are making history and most of the time, do so unconsciously. Hellenic history took its unique direction (with the Providence of God) because the country occupies an incomparable position and her people have a particular objective, which was to offer some possibilities to all humans to become persons (perfect personalities). It is very hard to describe truthfully and impossible to analyze the contribution of Greeks and their nation to European history. "The most important of them are to be found in ancient Greece, the world the Romans made, early Christianity, [the spiritual and godly Byzantine Empire] and the barbarian incursions into Western Europe in the closing of antiquity. Between them, they constituted the foundations of a future Europe", as Roberts ${ }^{[49]}$ says.

Less than two hundred years ago, in 1815 more than $3 / 4$ of all Europeans lived in rural villages or isolated homesteads and gained their living from the soil, but they have no psychological problems. In 1914, 
the majority in Western Europe (the Eastern and Balkan Europe was still in war to liberate its land from the Turks) lived in towns and cities and worked in factories, shops and offices ${ }^{[35]}$. In 1815 , the average life expectancy at birth was no more than 25 or 30 years; in 1914, it exceeded 50 years and was increasing rapidly. In 1815 , only the children of the well-to-do obtained the privilege of a formal education; the majority could neither read nor write. In the Eastern Europe, even that it was under Turkish occupation and revolution, the Orthodox Church (monks and monasteries) was offering education to children. By 1914 almost all European children could attend publicly supported elementary schools and acquire the elements of literacy. In 1815, most governments of Europe were more or less absolutist and aristocratic; participation in the process of government by means of elections was a privilege conferred only on wealthy landowners in a few countries bordering the western seas. By 1914, almost all European countries had some form of representative, if not wholly democratic government and in most countries the suffrage extended to all adult males.

On March 25, 1821, the revolution against Turkish rule broke out in Greece. Brutal fighting continued for several years between the unarmed Greeks and the barbarian conquerors, where Greece showed many heroes and martyrs to this just cause for her liberation. Unfortunately, by 1825 , the Turks had almost crushed the revolt. In Western Europe, sympathy for the Greeks (from the Philhellenes, like Lord Byron) ${ }^{[51]}$ mounted, in large part because of a sentimental regard for the contribution of the ancient Greeks to the development of Western civilization ${ }^{[34]}$. Unfortunately for Greece, the Ancient Greek and the Byzantine treasures have been looted by the European invaders (crusaders) and later, during the period of Greece's occupation by Turks. An example is the "Elgin Marbles"[39] and many other antiquities that "adorn" the foreign museums and testify the character of these nations. Great Britain, France and Russia agreed in the Treaty of London of 1827 to demand that the Ottoman Empire recognize Greek independence and to use force, if necessary, to end the fighting. An allied fleet defeated a Turkish and Egyptian force at Navarino in October 1827. After the liberation of Greece (only a small part of her territory because the $2 / 3$ of the country are still under occupation), the first governor was Ioannis Kapodistrias (1776-1831), from January 1828 to September 27, 1831, who was assassinated by a British conspiracy because he wanted the new nation to be independent from Western protectors and to be an Orthodox state in her faith ${ }^{[46]}$. In 1828, Russia declared war on Turkey and Russian forces moved into the Turkish-occupied
Danubian provinces of Moldavia and Wallachia (modern Rumania). Under the terms of the Treaty of Adrianople (1829), the Danubian provinces gained autonomy, as did Serbia and only Greece (Eastern Thrace, Eastern Rumelia, Constantinople, Asia Minor and Northern Cyprus) is even today under Turkish occupation. The Turks agreed to permit Russia, France and Great Britain to determine the future of Greece. In the Treaty of London (1830), the three powers recognized Greek Independence. In 1832, Otto (18321862 ), the son of the king of Bavaria, was chosen as king of Greece, who caused serious problems to the new country, due to his heterodox beliefs.

During the 1840s, economic problems intensified the discontent in Europe. The European economies had not fully recovered from the depression of 1837 and in much of Europe the 1840s were appropriately called "the hungry forties". In the Balkans, countries tried to gain their liberty from Turkish occupation. Crop failures and war increased the misery of the people and the workers in Europe's developing industries experienced continuing hardships. There were some revolutions in 1848, which were mainly from liberals, middle class and urban, not from workers and peasants. These liberals desired to establish constitutional governments where the power of monarchs would be limited by elected parliaments and guarantees of civil liberties. This was the liberal ideal that had taken shape during the Enlightenment and the French Revolution, but these liberal constitutional governments that Europe has from these days have cause more problems instead of solving any of them (they have become hereditary rulers controlled by the dark powers, which is worse than the royalty) ${ }^{[52]}$.

In addition, pseudo-philosophers and pseudoscientists appeared in 19th and 20th century, who abolished God and introduced the "third stage" in the human history, the scientific stage (or positive) (sic). The first stage, according to them was the religious one and the second the metaphysical one. Actually, the European civilization has accepted two man-made sub-cultures; the sub-culture of waste (capitalism), which will destroy humanity with its globalization in our days and the subculture of oppression (communism). Both have failed, but we try to preserve them because they satisfy the selfinterest of many ignorant people (who ignore the objective in life). Science became a cult that holds the answers to all humanity's questions. The question is now: Why do humans have so many psychological, personal and social problems after all these new scientific ideas? Too many atheists destroyed the entire European civilization. This materialism, liberalism, separation of church and state, secular education, civil 
marriage, promiscuity, led Europe slowly to today's crises in all sectors and with the integration, transfers its crises to every member-state. Even, value-oriented Greece (after joining the EU) lost completely her twothousand-year old Hellenic-Orthodox culture.

Following World War II, the idea of economic integration was promoted in Western Europe. Who were these people and what was their ultimate objective of this experiment were unknown. The world is waiting to see the conclusion of this union of nations, peoples, cultures, dogmas, histories, economies, politics and civilizations. The majority of Europeans are very skeptical and anxious for the future of their continent and of their nations. In 1950, Jean Monnet (1888-1979) convinced Premier Robert Schuman (1886-1963) to support a plan for the integration of the coal and steel industries of France and West Germany. Negotiations on the Schuman Plan led to the establishment in 1951 of the European Coal and Steel Community (ECSC). The ECSC included France, West Germany, Italy, Belgium, the Netherlands and Luxembourg. The success of the ECSC helped advance an even bolder proposal developed by Monnet. In 1957, the six members of the ECSC signed the Treaty of Rome establishing the European Economic Community (EEC), known as the Common Market. The members of this Common Market committed themselves to eliminate trade barriers and to promote free movement of capital and labor ${ }^{[42,47]}$.

The economic motive of the Union rests upon the argument that larger markets will promote greater specialization and increased competition, thus higher productivity and standards of living. But, countries have different value systems and work ethics and they cannot be equalized. Unfortunately, nothing of these has happened. So far the cost of integration has exceeded the benefits for the Europeans. Citizens have lost their jobs, due to competition from the other country-members. Prices have increased because of the common market and common currency, goods are moving to markets with higher prices and to attract them you have to pay the same high prices. Salaries are completely different among the members. Finally, illegal immigrants, drug dealers, terrorists, international mafia, every corrupted person and every kind of criminality move freely from one nation to the other because borders have been abolished. Greece has become an "unfenced vineyard".

The Common Market treaty took effect on January 1, 1958 and on July 1, 1968, all tariffs between member nations (France, Germany, Italy, Belgium, the Netherlands and Luxembourg) were completely eliminated, several years earlier than the date originally foreseen. In 1961, Britain signified its willingness to enter the Common Market if certain conditions could be met, but in January 1963, president de Gaulle of France in effect vetoed Britain's membership, an action he repeated in 1967 and 1969. The accession of Britain, Ireland and Denmark took effect on January 1, 1973. Greece acceded to the Community on January 1, 1981, without a referendum and Spain and Portugal on January 1, 1986. On January 1, 1995, the EU-12 became EU-15, with the accession of Austria, Finland and Sweden. On May 1, 2004 ten new members joined the Union: Poland, Hungary, the Czech Republic, Slovakia, Slovenia, Estonia, Latvia, Lithuania, Cyprus and Malta. Lately, on January 1, 2007, Romania and Bulgaria became EU members, reaching the implausible number of EU-27.

Thus, the past thirty years, a new world economic and political system based on interdependence, integration and deregulation has emerged. This process of internationalization, creation of multinational firms, acceptance of oligopolies and the growth of intensive economic cooperation were expected by some misinformed people to contribute to the increase of efficiency and wealth (but not the welfare, stability and safety) in the participating countries. So far, we have seen an increase in unemployment, in inflation, in unfair distribution of this wealth, in inequalities, in backwardness, in degradation of human civilization, in dependency, in uncertainty, in terrorism, in criminality and above all in greediness, in injustice, in oppression and in corruption everywhere. The recent (during the 1990s) high level of economic development in the industrial west might be based on the new technology and on international economic cooperation; tremendous liquidity, privatization and financial markets glorification, but at the same time enabling complex exploitation of third world countries, as it happened in the 18th, 19th and 20th centuries, of the small investors and of the factor labor everywhere (except the one provided by CEOs, public servants and politicians). Many of these developing countries have caused serious trade deficits and unemployment in EU because of their low cost of production and their devaluated currencies. China has become an enormous economic and social threat for EU. A serious problem that the west faces from China is not only the low cost of production, but the different moral and ethical standards between the two cultures. The Chinese are reproducing fakes of many western products. Greece leased the seaport of Piraeus to Chinese for 30 years, so they can import everything in Europe.

Later, in February 1992, the Maastricht Treaty was signed but it, then, had to be ratified by all the member states. This process went "well" because the state 
governments did not hold a referendum for ratification of the treaty by their citizens. Denmark voted "no" on June 2, 1992 in a referendum and then the following day France announced that it would hold a referendum. Eleven years later, on September 14, 2003, Sweden had a referendum and $56.2 \%$ said "no" to the EMU. Unfortunately, in September 1992, after Germany's reunification, there was a crisis, which resulted in the pound sterling and Italian lira leaving the system and at the same time peseta was devaluing by 5 percent. Also, in August 1993, there was a further crisis, in which even currencies with sound fundamentals were attacked. The EC, under this pressure, broaden the fluctuation bands within the ERM to $15 \%$ from $2.25 \%$. In March 1996, the peseta and the escudo were devalued by 7 and 3\%, respectively. Then, the original plan in this area has gone well off track, but they did not plan to abandon it. For this monetary union to begin on January 1, 1999, prior to 1999 (on December 31, 1997), a majority of countries should have met the five criteria (gross government debt/GDP, budget deficit/GDP, 10-year government bond yield, inflation rate and ERM member) established by the Maastricht Treaty. Nevertheless, in 1999, according to the treaty, EMU would commence for those countries, which had converged (however it looked, they were only very few, actually, Luxembourg and France), but eleven of them had been confirmed by the European Commission. The twelfth country (Greece) joined a little later and the thirteenth one (Slovenia) became an EMU member on January 1, 2007. Cyprus and Malta qualified in 2007 and were admitted on 1 January 2008. Slovakia qualified in 2008 and joined on 1 January 2009. At the moment there are 16 member states with over 326 million people in the euro-zone.

The European Union has to develop a "social dimension" together with its adoption of the "social free market" model, which has to be regulated, because of the Maastricht treaty and its serious unemployment, inflation and recession problems that it experiences since the integration. During the $1960-73$ periods up until the first oil price shock, the average annual level of unemployment was around $2.6 \%$ with an economic growth rate of $4.8 \%$. Between 1974 and 1985 the unemployment rate rose to $10.8 \%$ by 1985 , while economic growth dropped back to $2 \%$. In the period 1989-90, with an increase in economic growth to $3.2 \%$, the unemployment rate dropped to $8.3 \%$ in $1990^{[28]}$. In the meantime, it can hardly be said that there have been dramatic improvements in the EU unemployment situation because in 2003 it was over 9\% with an economic growth of $0.5 \%$ for the Euro Area. Today (Spring 2009), the unemployment is $9 \%$ and in Greece must be in double digits up to $40 \%$ in some regions; and the real GDP growth is negative (deep recession) in all over Europe. The integration has increased unemployment further as Roberts ${ }^{[56]}$ said. Also, the reduction of national debt, through privatization of public enterprises, has contributed to the growth of unemployment. The uncontrolled illegal migration has caused unemployment, too ${ }^{[16-18]}$ and it would be worse in the near future, due to the current financial crisis and the difficulties towards assimilation of these nonEuropeans $^{[11,12]}$.

Further, the euro was introduced in electronic form on January 1, 1999 and in banknotes on January 1, 2002. Richard Alm said that "Europe embarked upon monetary union much the way Columbus set out across the Atlantic in 1492-full of hope but without a map". Nothing similar to this EMU had ever been tried before in human history. A total of 16 countries with a hodgepodge of languages, dogmas, cultures, customs, values, economies, productivities, products, needs and behaviors tied their economic, political, constitutional, legal and social future to a common artificial supranational creature, the EMU. Today, 326 million people, the citizens of these 16 nations are in the worst socio-economic crisis in their history. The Governor of the Bank of France, Christian Noyer had said that "EMU in Europe will never happen, but if it does happen, it will be a disaster". Today, this is the view of every Euro-zone citizen, "Euro has destroyed their lives". The European Central Bank (ECB) has defined price stability as consumer inflation of less than $2 \%$. How can this mandate be delivered? By buying everything from China and causing from $10 \%$ to $40 \%$ unemployment in some regions? EMU has not been successful in stimulating the economies of EU. The euro area has grown more slowly than the US, with most of the poor performance arising from these new structural supranational monsters, the EMU and the EU. In 1999 and 2000, the euro fell against the dollar, reaching a low value of $\$ 0.82$ in October 2000. After 2002 , the currency rose, peaking at $\$ 1.3646$ on December 30, 2004, then it declined at $\$ 1.1929$ on July 6, 2005 and picked at $\$ 1.6001$ (4/22/2008); today $(6 / 1 / 2009)$ it is up again at $\$ 1.4191$. Country-members of the Euro-zone have lost their monetary policy and they cannot reduce their inflation ${ }^{[32]}$. Then, their only hope was their fiscal policy, but the Maastricht criteria do not allow governments to run budget deficits, even when they are in a recession, as they currently are. Finally, they have been left without any public policy tool. Also, this overvalued single currency has eliminated foreign investment, has deteriorated exports and has increased imports in EMU countries. 
Businesses', farmers' and households' borrowing has increased so much that bankruptcy is the most common process in this common currency area ${ }^{[20]}$.

The global financial crisis of 2008 affected negatively Greece and the government tried to reduce its effect on the real sector of the economy by offering a package of 28 billion euros to the banks. This crisis brought to the surface the structural weaknesses of the Greek economy (a capitalistic economy controlled by the EU and based on governmental support). The governmental debt from 172 billion euros in 2002 reached 252 billion euros in 2008 (a +47\% growth). The trade deficit from -27 billion euros in 2005, became -42 billion euros in 2007 ( $+55 \%$ growth). The budget was in a deficit of -19 billion euros in the first half of the 2008. The country has, currently, a very high unemployment and a high inflation, but salaries are low compared to other members of the EMU. EU is pressing Greece to impose property tax of $9 \%$ on the first home of her citizens. So far Greece had no property taxes. It seems that capitalism is gradually imitating communism; we are going to end up without property with all these duties, compulsory insurance and taxes on ownership of homes and on other physical assets (dwellings).

The unemployment is a very serious problem for the country. A businessman from Thessaloniki said that the unemployment in the area is $20 \%$. ECB reduced the overnight rate to $3.25 \%$ and EU announced that will offer 200 billion euros to country-members for support because of the financial crisis. Greece will receive 3 billion euros from this package. Greek government gave 600 million euros to the low income families (allowances for heating cost, to small businesses and to families). England is reducing the value added tax to stimulate consumption, but not Greece. Farmers in Thessaly and other parts of Greece started their demonstrations closing roads with their tractors, due to the low prices on their unsold products. The OECD is predicted a very high unemployment in Greece (it seems like $12 \%$ at the moment with regions of $40 \%$ unemployment rate). Of course, one major fiscal problem of the country is the tax evasion by the wealthy people and professionals. The minister of finance said that homes bigger than $150 \mathrm{~m}^{2}$ will be taxed (so far home above $200 \mathrm{~m}^{2}$ were taxed).

Unfortunately, with the illegal immigrants and especially with the inflow of many criminals after the opening of prisons in Albania, Greece has daily robberies of homes, people, stores, cars and kidnapping of individuals. The illegal migration is the most serious problem that Greece faces the last 15 years and is becoming worse. These people do not respect the country, its laws, its culture and its values, especially the Muslim ones (Albanians, Turks and other Asians). Their criminality is unique in the country's history and Greek citizens are abandoning their homes and their stores, due to these problems. The market value of housing and of any property has fallen too low because of the ghettos that have been created in some regions (i.e., Agios Padeleimon in Athens).

Finally, tourism has declined drastically (more than $40 \%$ in the winter resorts and will be the same in summer of 2009), due to the global financial crisis and the high prices from the euro. Even Greeks are going abroad for their vacations where the cost is lower. Also, $\mathrm{S}$ and $\mathrm{P}$ cut Greece's credit rating as her economy deteriorates and the national debt is increasing. Further, a Greek terrorist group "Epanastatikos Agonas" (Revolutionary Fight) claimed responsibility for recent attacks on police in Athens. Even though that the country is struck by everyone, it tries to continue with her "competitive advantage", her education (paideia), civilization and culture. Greece opened a Center of Hellenic Studies in Alexandria, Egypt. With respect the economy, the ECB reduced the overnight rate to $2 \%$ and Greece issued a 10-year maturity Treasury bond; later the ECB cut its rate to $1.25 \%$ and on May 8, 2009, it cut the interest rate to $1 \%$. Our hypothesis is that the cost of Greece's integration and abandonment of her currency (drachma) exceeds the benefits.

\section{MATERIALS AND METHODS}

A loss to society function: A loss to society function $^{[32,30]}$ can be expressed as a weighted average of deviations of unemployment from its target, of risk, interest rate, inflation, output, saving, money supply, trade balance, national debt and financial market from their potential levels ${ }^{[16,17,31]}$ :

$$
\begin{aligned}
\mathrm{L}= & \mathrm{w}_{\mathrm{u}}\left(\mathrm{u}-\mathrm{u}^{*}\right)+\mathrm{w}_{\mathrm{R}}\left(\mathrm{d}-\mathrm{d}^{*}\right)+\mathrm{w}_{\mathrm{i}}\left(\mathrm{i}-\mathrm{i}^{*}\right) \\
& +\mathrm{w}_{\pi}\left(\pi-\pi^{*}\right)+\mathrm{w}_{\mathrm{q}}\left(\dot{\mathrm{q}}^{*}-\dot{\mathrm{q}}\right)+\mathrm{w}_{\mathrm{S}}\left(\mathrm{s}^{*}-\mathrm{s}\right) \\
& +\mathrm{w}_{\mathrm{m}}\left(\dot{\mathrm{m}}^{\mathrm{s}}-\dot{\mathrm{m}}^{* \mathrm{~s}}\right)+\mathrm{w}_{\mathrm{ta}}\left(\mathrm{ta}^{*}-\mathrm{ta}\right) \\
& +\mathrm{w}_{\mathrm{nd}}\left(\mathrm{nd}^{*}-\mathrm{nd}\right)+\mathrm{w}_{\mathrm{SMI}}\left(\mathrm{g}_{\mathrm{SMI}}{ }^{*}-\mathrm{g}_{\mathrm{SMI}}\right)
\end{aligned}
$$

Where:

$\Sigma \mathrm{W}=1$

$\mathrm{L} \quad=$ The loss to society

$\mathrm{u} \quad=$ The unemployment rate

$\mathrm{d} \quad=\operatorname{Risk}\left(\mathrm{RP}=\mathrm{i}_{\mathrm{GB}}-\mathrm{i}_{\mathrm{TB}}\right)$

$\mathrm{i}=$ Nominal short-term interest rate (Treasury bill rate or overnight deposit rate of the ECB)

$\pi=$ Inflation rate 


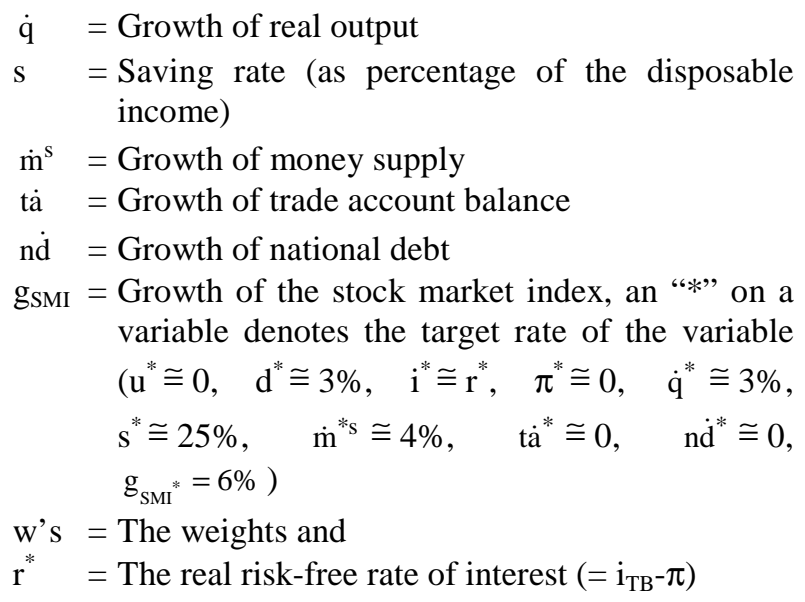

Any deviation of the actual value of the above variables from their targets will cause a loss for the society. Of course, the social objective will be the minimization of this social loss (L).

Convergence and interdependence between Greece and EMU: The model is a partial equilibrium open economy Macroeconomic one, which comprises the aggregate supplies, demands, money markets and the foreign sector (balance of payments) in both entities (Greece and EMU). Its structure contains foreign variables (Euro-zone's) that we can test the interdependence between the economies, their transmission mechanism and policy variables by which the public policy effectiveness will be examined. The theoretical model is taking into consideration the works by ${ }^{[1,3,7,9,10,13-15,17,22-27,29,30,36,38,40,48,50,53-55]}$. The general two-country model is as follows:

( $\alpha$ ) The Aggregate Supply (AS): For the domestic (Greek) economy, it can be written as follows:

$$
\begin{aligned}
\mathrm{Y}= & \mathrm{F}\left[\mathrm{P}, \mathrm{w}, \frac{\mathrm{EP}}{\mathrm{P}}, \mathrm{P}_{\text {oil }}, \mathrm{u}\right] \\
& \mathrm{F}_{\mathrm{P}}>0, \mathrm{~F}_{\mathrm{w}}<0, \mathrm{~F}_{\frac{\mathrm{EP}^{*}}{\mathrm{P}}}<0, \mathrm{~F}_{\mathrm{P}_{\text {oil }}}<0, \mathrm{~F}_{\mathrm{u}}<0
\end{aligned}
$$

And for the EU:

$$
\begin{aligned}
\mathrm{Y}^{*}= & \mathrm{F}^{*}\left[\mathrm{P}^{*}, \mathrm{w}^{*}, \frac{\mathrm{EP} *}{\mathrm{P}}, \mathrm{P}_{\mathrm{oil}}, \mathrm{u}^{*}\right] \\
& \mathrm{F}_{\mathrm{P}^{*}}^{*}>0, \mathrm{~F}_{\mathrm{w}^{*}}^{*}<0, \frac{\mathrm{F}_{\frac{\mathrm{EP}}{\mathrm{P}}}^{*}}{\mathrm{P}}>0, \mathrm{~F}_{\mathrm{P}_{\mathrm{oil}}}<0, \mathrm{~F}_{\mathrm{u}^{*}}^{*}<0
\end{aligned}
$$

Where:

$$
\begin{array}{ll}
\mathrm{Y} & =\text { Real income (output) } \\
\mathrm{P} & =\text { The price level } \\
\mathrm{W} & =\text { Wage rate }
\end{array}
$$

$$
\begin{aligned}
& \frac{E P *}{P}=\frac{P_{M}}{P_{X}}=\text { TOT }=\text { The terms of trade (the real exchange } \\
& \text { rate) } \\
& \mathrm{E} \quad=\text { Exchange rate }(\$ / €) \\
& \mathrm{P}_{\mathrm{oil}} \quad \text { = Price of oil } \\
& \mathrm{u} \quad=\text { Unemployment rate } \\
& \text { An asterisk }(*)=\text { The foreign country (EMU as a } \\
& \text { whole) }
\end{aligned}
$$

Solving Eq. 2 for $\mathrm{P}$, we receive the AS function, which is positively sloped in $\mathrm{P}-\mathrm{Y}$ space:

$\mathrm{P}=\mathrm{AS}\left[\mathrm{Y}, \mathrm{w}, \frac{\mathrm{EP}^{*}}{\mathrm{P}}, \mathrm{P}_{\mathrm{oil}}, \mathrm{u}\right]$

And for the Euro-zone, from Eq. 3, we get the AS* curve:

$\mathrm{P}^{*}=\mathrm{AS}^{*}\left[\mathrm{Y}^{*}, \mathrm{w}^{*}, \frac{\mathrm{EP}}{\mathrm{P}}, \mathrm{P}_{\mathrm{oil}}, \mathrm{u}^{*}\right]$

( $\beta$ ) The Aggregate Demand (AD): The Greek aggregate demand can be presented as follows:

$$
\begin{aligned}
\mathrm{Y}= & \mathrm{D}\left[\mathrm{P}, \frac{\mathrm{EP}^{*}}{\mathrm{P}}, \mathrm{M}, \mathrm{C}, \mathrm{I}, \mathrm{G}, \mathrm{X}, \mathrm{X}^{*}, \mathrm{Y}^{*}\right] \\
& \mathrm{D}_{\mathrm{P}}<0, \mathrm{D}_{\frac{\mathrm{EP}^{*}}{\mathrm{P}}}>0, \mathrm{D}_{\mathrm{M}}>0, \mathrm{D}_{\mathrm{C}}>0, \mathrm{D}_{\mathrm{I}}>0, \\
& \mathrm{D}_{\mathrm{G}}>0, \mathrm{D}_{\mathrm{X}}>0, \mathrm{D}_{\mathrm{X}^{*}}<0, \mathrm{D}_{\mathrm{Y}^{*}}>0
\end{aligned}
$$

And for the European Union:

$$
\begin{aligned}
& \mathrm{Y}^{*}= \mathrm{D}^{*}\left[\mathrm{P}^{*}, \frac{\mathrm{EP}}{\mathrm{P}}, \mathrm{M}^{*}, \mathrm{C}^{*}, \mathrm{I}^{*}, \mathrm{G}^{*}, \mathrm{X}, \mathrm{X}^{*}, \mathrm{Y}\right] \\
& \mathrm{D}_{\mathrm{P}^{*}}^{*}<0, \mathrm{D}_{\frac{\mathrm{EP}^{*}}{\mathrm{P}}}^{*}<0, \mathrm{D}_{\mathrm{M}^{*}}^{*}>0, \mathrm{D}_{\mathrm{C}^{*}}^{*}>0, \mathrm{D}_{\mathrm{I}^{*}}^{*}>0, \\
& \mathrm{D}_{\mathrm{G}^{*}}^{*}>0, \mathrm{D}_{\mathrm{X}}^{*}<0, \mathrm{D}_{\mathrm{X}}^{*}>0, \mathrm{D}_{\mathrm{Y}}^{*}>0
\end{aligned}
$$

Where:

$$
\begin{array}{ll}
\mathrm{M} & =\text { The money supply } \\
\mathrm{C} & =\text { Private consumption } \\
\mathrm{I} & =\text { Private investment } \\
\mathrm{G} & =\text { Government spending } \\
\mathrm{X} & =\text { Exports } \\
\text { An asterisk }(*) & =\text { The foreign country (EMU) }
\end{array}
$$

By solving Eq. 6 and 7 for $\mathrm{P}$ and $\mathrm{P}^{*}$, we determined the $\mathrm{AD}$ and $\mathrm{AD}^{*}$ function, which are negatively sloped in P-Y space:

$$
\mathrm{P}=\mathrm{AD}\left[\mathrm{Y}, \frac{\mathrm{EP}^{*}}{\mathrm{P}}, \mathrm{M}, \mathrm{C}, \mathrm{I}, \mathrm{G}, \mathrm{X}, \mathrm{X}^{*}, \mathrm{Y}^{*}\right]
$$


And:

$\left.\mathrm{P}^{*}=\mathrm{AD} * \mathrm{Y}^{*}, \frac{\mathrm{EP}^{*}}{\mathrm{P}}, \mathrm{M}^{*}, \mathrm{C}^{*}, \mathrm{I}^{*}, \mathrm{G}^{*}, \mathrm{X}, \mathrm{X}^{*}, \mathrm{Y}\right]$

( $\gamma$ ) The Money Market equilibrium (LM): The domestic money market equilibrium shows that real money supply is equal to real money demand and equal to the stock of money:

$$
\begin{aligned}
\frac{M}{P}= & L(Y, i, E) \\
& L_{Y}>0, L_{i}<0, L_{E}>0
\end{aligned}
$$

And:

$$
\begin{aligned}
\frac{\mathrm{M}^{*}}{\mathrm{P}^{*}}= & \mathrm{L}^{*}\left(\mathrm{Y}^{*}, \mathrm{i}^{*}, \mathrm{E}\right) \\
& \mathrm{L}_{\mathrm{Y}^{*}}^{*}>0, \mathrm{~L}_{\mathrm{i}^{*}}^{*}<0, \mathrm{~L}_{\mathrm{E}}^{*}>0
\end{aligned}
$$

Where:

$\mathrm{M}=$ The money supply and

$\mathrm{E}=$ The exchange rate (we can use $\$ / €$, here, to determine the competitiveness of the country with respect the US economy)

Equation 10 can be solved for $\mathrm{i}$ and the LM curve is provided:

$\mathrm{i}=\mathrm{LM}(\mathrm{Y}, \mathrm{M}, \mathrm{P}, \mathrm{E})$

For the EMU the $\mathrm{LM}^{*}$ locus is:

$i^{*}=\mathrm{LM}^{*}\left(\mathrm{Y}^{*}, \mathrm{M}^{*}, \mathrm{P}^{*}, \mathrm{E}\right)$

(ס) The Balance of Payments equilibrium: The Greek balance of payments can be written as:

$$
\begin{gathered}
\mathrm{BP}=\mathrm{T}\left(\mathrm{Y}^{*}, \mathrm{Y}, \mathrm{i}-\mathrm{i}^{*}, \mathrm{E}, \frac{\mathrm{EP}^{*}}{\mathrm{P}}\right)+\mathrm{K}\left(\mathrm{i}-\mathrm{i}^{*}, \mathrm{E}\right) \\
\mathrm{T}_{\mathrm{Y}^{*}}>0, \mathrm{~T}_{\mathrm{Y}}<0, \mathrm{~T}_{\mathrm{i}-\mathrm{i}^{*}}<0, \mathrm{~T}_{\mathrm{E}}>0, \mathrm{~T}_{\frac{\mathrm{EP}^{*}}{\mathrm{P}}}>0, \\
\mathrm{~K}_{\mathrm{i}-\mathrm{i}^{*}}>0, \mathrm{~K}_{\mathrm{E}}<0
\end{gathered}
$$

And the Euro-zone one as follows:

$$
\begin{aligned}
\mathrm{BP}^{*}= & \mathrm{T}^{*}\left(\mathrm{Y}, \mathrm{Y}^{*}, \mathrm{i}-\mathrm{i}^{*}, \mathrm{E}, \frac{\mathrm{EP}}{\mathrm{P}}\right)+\mathrm{K}^{*}\left(\mathrm{i}-\mathrm{i}^{*}, \mathrm{E}\right) \\
& \mathrm{T}_{\mathrm{Y}}^{*}>0, \mathrm{~T}_{\mathrm{Y}^{*}}^{*}<0, \mathrm{~T}_{\mathrm{i}-\mathrm{i}^{*}}^{*}>0, \mathrm{~T}_{\mathrm{E}}^{*}<0, \mathrm{~T}_{\frac{\mathrm{EP}^{*}}{\mathrm{P}}}^{*}<0, \\
& \mathrm{~K}_{\mathrm{i}-\mathrm{i}^{*}}^{*}<0, \mathrm{~K}_{\mathrm{E}}^{*}<0
\end{aligned}
$$

Where:

$\mathrm{BP}=$ Balance of payments

$\mathrm{T}=$ Current (trade) account

$\mathrm{K}$ = capital account

From Eq. 14, solving for i, we can determine the BP locus for Greece:

$i=B P\left(Y, Y^{*}, i^{*}, E, \frac{E P^{*}}{P}\right)$

From Eq. 15, we can determine the $\mathrm{BP}^{*}$ locus for the EMU (Euro-zone):

$i^{*}=B^{*}\left(Y^{*}, Y, i, E, \frac{E P^{*}}{P}\right)$

In order to solve the system, we can utilize Keynes ${ }^{[45]}$ and Hicks ${ }^{[6]}$ apparatus. This simply entails adopting the strategy of collapsing the equations of the model into a system of two equations, the $\mathrm{AD}$ and $\mathrm{AS}$ functions: One equation, the money market (LM): And a third one, the Balance of Payments line (BP) for each economy. The ultimate objective will be to estimate the coefficients of these variables and to find the size of these effects (transmission mechanism) between each of the two entities (Greece and Euro-zone). Also, to determine the size of the effects of the external shocks on our endogenous variables and the effects of the policy variables (instruments) on the variables in question.

In other words, we want to examine the effects of a supply shock, demand shock and money supply shocks on output and prices. Also, capital flow shocks will be important; especially lately, due to the Iraqi war many Muslims are investing their funds in EU instead of investing them in the US because they are afraid that USA might freeze their funds in the future ${ }^{[13-15]}$. We will try to identify the effects of the different shocks and the effectiveness of public policies within a structural Vector Autoregression (VAR) framework and to see their impulse responses on the target variables ( $\mathrm{y}, \mathrm{p}$ and $\mathrm{u})$.

Data, stationarity and cointegration testing and empirical results:

Data: The data are monthly mostly from 1999:012008:12 (there are some series from 1974:01-2008:12) and are coming from economagic.com, imfstatistics.org and Eurostat. They comprise the variables, income or GDP (Y), consumption (C), government spending (G), money supply $\left(\mathrm{M}^{\mathrm{s}}\right)$, a variety of interest rates (S-T and $\mathrm{L}-\mathrm{T}$, but emphasis will be given to ECB overnight rate, as policy instrument), exports (X) and imports (M), prices (CPI), wages and salaries (w), unemployment 
rate $(\mathrm{u})$, exchange rate $[\mathrm{E}(\$ / €)]$, price of oil $\left(\mathrm{P}_{\mathrm{oil}}\right)$ and a few others. In the first analysis, we look at some empirical evidence of interdependence between Greece and the EMU, macroeconomic shocks ( $\mathrm{P}_{\text {oil }}$, wages $)$ and the effectiveness of monetary (M, i) and fiscal (G) policies. Such evidence can be provided by correlations, causality, regression analysis and a Vector Autoregression (VAR) to test the dynamic impact of the econometric models presented in the theory. Consider now an EMU expansion. We will test the hypotheses that the price of oil has a negative effect on production and a positive on prices, the growth in EMU will affect positively Greece's production and the overvalued euro will affect negatively the trade account of Greece and finally, the public policies will have positive effects on the economy. We expect that when the income in the EMU will rise, Greece's economy is improved. But we will test spillover effects of the EMU expansion. In Greece, income is expected to rise, too. This will be an evidence of a strong interdependence through induced changes in imports and due to integration and common currency.

Test of stationarity and cointegration of the variables: The unit root issue is important in the context of the standard regression model. The assumptions of the classical model necessitate that dependent and independent variables must be stationary and the error terms must have the following properties (assumptions):

$\mathrm{E}\left(\varepsilon_{\mathrm{t}}\right)=0, \quad \mathrm{E}\left(\varepsilon_{\mathrm{t}}^{2}\right)=\sigma^{2}$

And:

$\mathrm{E}\left(\varepsilon_{\mathrm{t}}, \varepsilon_{\mathrm{t}-1}\right)=0$

In the presence of nonstationary variables, there might be a spurious regression ${ }^{[5,41]}$. In this case, the regression equation must be estimated in first differences. If the nonstationary variables are integrated of the same order and the residual is stationary, the two series are cointegrated. We test the variables in our regressions for stationarity by using a Dickey-Fuller ${ }^{[2]}$ and a Phillips-Perron ${ }^{[33]}$ test $^{[2]}$ and for cointegration by using Johansen ${ }^{[7,43]}$ methodology.

The finding that most of the macro-variables contain a unit root has spurred the development of the theory of non-stationary time series analysis. Engle and Granger $^{[3]}$ pointed out that a linear combination of two or more non-stationary series may be stationary. If such a stationary linear combination exits, the non-stationary time series are said to be cointegrated. This stationary linear combination is called the cointegrating equation and may be interpreted as a long-run equilibrium relationship among the variables.

Consider the logarithmic linear equation of the money market equilibrium, Eq. 10, which can be written as:

$$
\begin{aligned}
\mathrm{m}_{\mathrm{t}}-\mathrm{p}_{\mathrm{t}}= & \alpha_{0}+\alpha_{1} \mathrm{y}_{\mathrm{t}}+\alpha_{2} \mathrm{i}_{\mathrm{t}}+\alpha_{3} \mathrm{e}_{\mathrm{t}} \\
& +\varepsilon_{\mathrm{t}} \alpha_{1}>0, \alpha_{2}<0, \alpha_{3}<0
\end{aligned}
$$

Where:

$\mathrm{m}_{\mathrm{t}}-\mathrm{p}_{\mathrm{t}}=$ The real quantity of money balances

$\mathrm{y}_{\mathrm{t}} \quad=$ The real income

$\mathrm{i}_{\mathrm{t}} \quad=$ The interest rate (opportunity cost of holding money)

$\mathrm{e}_{\mathrm{t}} \quad=$ The exchange rate $(\$ / €)$

$\epsilon_{\mathrm{t}} \quad=$ The stationary disturbance term

$\alpha_{\mathrm{j}} \quad=$ Parameters to be estimated

All the variables, except the interest rate, are expressed in natural logarithms $\left(\mathrm{m}_{\mathrm{t}}=\ln \mathrm{M}_{\mathrm{t}}\right)$; lower case letters are the ln of the capital ones.

For the theory to make any sense at all, any deviation in the demand for money must necessarily be temporary in nature. If $\varepsilon_{\mathrm{t}}$ has a stochastic trend, the errors in the model will be cumulative so that deviations from money market equilibrium will not be eliminated. Hence, a key assumption of the theory is that the $\left\{\varepsilon_{\mathrm{t}}\right\}$ sequence is stationary. The problem confronting, here, is that $\mathrm{m}_{\mathrm{t}}, \mathrm{p}_{\mathrm{t}}, \mathrm{y}_{\mathrm{t}}$ and $\mathrm{e}_{\mathrm{t}}$ are nonstationary $[\mathrm{I}(1)]$ variables, except $i_{t}$, which is stationary $[\mathrm{I}(0)]$. As such, these nonstationary variables can meander without any tendency to return to a longrun level. However, the theory expressed in Eq. 10 insists that there exists a linear combination of these nonstationary variables that is stationary.

Solving Eq. 18 for the error term, we can rewrite it as:

$\varepsilon_{\mathrm{t}}=\mathrm{m}_{\mathrm{t}}-\mathrm{p}_{\mathrm{t}}-\alpha_{0}-\alpha_{1} \mathrm{y}_{\mathrm{t}}-\alpha_{2} \mathrm{i}_{\mathrm{t}}-\alpha_{3} \mathrm{e}_{\mathrm{t}}$

Since, $\left\{\varepsilon_{\mathrm{t}}\right\}$ must be stationary, it follows that the linear combination of integrated variables given by the right-hand side of Eq. 19 must also be stationary. Thus, the theory necessitates that the time paths of the four nonstationary variables $\left\{\mathrm{m}_{\mathrm{t}}\right\},\left\{\mathrm{p}_{\mathrm{t}}\right\},\left\{\mathrm{y}_{\mathrm{t}}\right\}$ and $\left\{\mathrm{e}_{\mathrm{t}}\right\}$ be linked. The aggregate supply and aggregate demand functions, the money market equilibrium and the balance of payments, here, are examples of stationary combinations of mostly nonstationary variables. Of course, within any equilibrium framework, the deviations from equilibrium must be temporary. The purpose of these cointegration tests is to determine 
whether our group of nonstationary series are cointegrated or not. The cointegration tests for our multi-variables models took place, here, by using a Johansen and Juselius ${ }^{[8]}$ method.

In addition, a Vector Autoregression (VAR) is used, for the above forecasting system of the interdependent variables between Greece and EMU and the policy variables, to analyze the dynamic impact of random disturbances on the system of variables. The VAR approach sidesteps the need for structural modeling by treating every endogenous variable in the system (Y, $\mathrm{Y}^{*}, \mathrm{P}, \mathrm{P}^{*}, \mathrm{u}, \mathrm{u}^{*}$, plus some policy exogenous variables $\left.\mathrm{M}^{\mathrm{s}}, \mathrm{i}, \mathrm{G}\right)$ as a function of the lagged values of all of the endogenous variables in the system.

For example, suppose that real income $\left(y_{t}\right)$, prices $\left(\mathrm{p}_{\mathrm{t}}\right)$ and unemployment $\left(\mathrm{u}_{\mathrm{t}}\right)$ are jointly determined by a VAR and let a policy variable $\left(\mathrm{x}_{\mathrm{t}}\right)$ be the exogenous variable:

$$
\begin{aligned}
\mathrm{y}_{\mathrm{t}}= & \mathrm{a}_{11} \mathrm{y}_{\mathrm{t}-1}+\mathrm{a}_{12} \mathrm{p}_{\mathrm{t}-1}+\mathrm{a}_{13} \mathrm{u}_{\mathrm{t}-1}+\mathrm{b}_{11} \mathrm{y}_{\mathrm{t}-2} \\
& +\mathrm{b}_{12} \mathrm{p}_{\mathrm{t}-2}+\mathrm{b}_{13} \mathrm{u}_{\mathrm{t}-2}+\mathrm{c}_{11} \mathrm{x}_{\mathrm{t}}+\varepsilon_{1 \mathrm{t}} \\
\mathrm{p}_{\mathrm{t}}= & \mathrm{a}_{21} \mathrm{y}_{\mathrm{t}-1}+\mathrm{a}_{22} \mathrm{p}_{\mathrm{t}-1}+\mathrm{a}_{23} \mathrm{u}_{\mathrm{t}-1}+\mathrm{b}_{21} \mathrm{y}_{\mathrm{t}-2} \\
& +\mathrm{b}_{22} \mathrm{p}_{\mathrm{t}-2}+\mathrm{b}_{23} \mathrm{u}_{\mathrm{t}-2}+\mathrm{c}_{21} \mathrm{x}_{\mathrm{t}}+\varepsilon_{2 \mathrm{t}} \\
\mathrm{u}_{\mathrm{t}}= & \mathrm{a}_{31} \mathrm{y}_{\mathrm{t}-1}+\mathrm{a}_{32} \mathrm{p}_{\mathrm{t}-1}+\mathrm{a}_{33} \mathrm{u}_{\mathrm{t}-1}+\mathrm{b}_{31} \mathrm{y}_{\mathrm{t}-2} \\
& +\mathrm{b}_{32} \mathrm{p}_{\mathrm{t}-2}+\mathrm{b}_{33} \mathrm{u}_{\mathrm{t}-2}+\mathrm{c}_{31} \mathrm{x}_{\mathrm{t}}+\varepsilon_{3 \mathrm{t}}
\end{aligned}
$$

Where:

$\mathrm{y}_{\mathrm{t}}, \mathrm{p}_{\mathrm{t} \text { and }} \mathrm{u}_{\mathrm{t}}=\mathrm{K}$ vectors of these three endogenous variables

$\mathrm{x}_{\mathrm{t}} \quad=$ A d vector of exogenous variables

$\mathrm{a}_{\mathrm{ij}}, \mathrm{b}_{\mathrm{ij}}, \mathrm{c}_{\mathrm{ij}} \quad=$ The parameters to be estimated

$\varepsilon_{1 \mathrm{t}}, \varepsilon_{2 \mathrm{t}}$ and $\varepsilon_{3 \mathrm{t}}=$ Three vectors of innovations that may be contemporaneously correlated, but are uncorrelated with their own lagged values and uncorrelated with all the right-hand side variables

If the innovations $\varepsilon_{\mathrm{t}}$ 's are contemporaneously uncorrelated, interpretation of the impulse response is straightforward. The ith innovation $\varepsilon_{\mathrm{I}, \mathrm{t}}$ is simply a shock to the ith endogenous variable $y_{i}, t$. Innovations, however, are usually correlated and may be viewed as having a common component, which cannot be associated with a specific variable. In order to interpret the impulses, it is common to apply a transformation $\mu$ to the innovations so that they become uncorrelated:

$\mu_{\mathrm{t}}=\mu \varepsilon_{\mathrm{t}} \sim(0, \mathrm{D})$

Where:

$\mathrm{u}_{\mathrm{t}}=$ The residual

$\varepsilon_{\mathrm{t}}=$ The innovations

$\mathrm{D}=$ A diagonal covariance matrix

$\mu=$ The choice of transformation
We try to identify, first, a vector of structural shocks, $\varepsilon=\left[\varepsilon_{\mathrm{y}}, \varepsilon_{\mathrm{p}}, \varepsilon_{\mathrm{u}}\right]$ and we let the VAR consist of real outputs $\left(\mathrm{y}_{\mathrm{t}}\right.$ and $\left.\mathrm{y}_{\mathrm{t}}^{*}\right)$, price levels $\left(\mathrm{p}_{\mathrm{t}}\right.$ and $\left.\mathrm{p}_{\mathrm{t}}^{*}\right)$ and unemployment rates $\left(\mathrm{u}_{\mathrm{t}}\right.$ and $\left.\mathrm{u}_{\mathrm{t}}^{*}\right)$. Then, other combinations of cost variables and policy variables can be considered, too. Here, the real output $\mathrm{Y}$ is the real GDP $\left(\frac{\mathrm{GDP}}{\mathrm{CPI} / 100}\right)$, the $\mathrm{P}$ is the $\mathrm{CPI}$; policy instruments are, the money supply $\left(\mathrm{M}^{\mathrm{s}}\right)$, the interest rate $\left(\mathrm{i}_{\mathrm{OND}}^{*}\right)$ and the government spending $(\mathrm{G})$. Finally, an Impulse Response is performed, which shows how a shock to the ith variable affects itself and also is transmitted to all of the other endogenous variables through the dynamic (lag) structure of the VAR. The impulse response function traces the effect of a one-time shock to one of the innovations on current and future values of the endogenous variables.

\section{RESULTS AND DISCUSSION}

We divided the period from 1974-2008 into different sub-periods: First, from 1974:01-1980:12 (Greece joined the EC on January 1, 1981); second, from 1981:01-1992:12 (when the European integration took place and the EU was created); third, from 1981:01-2000:12 (where Greece joined the EMU on January 1, 2001); fourth, from 2001:01-2001:12 (Greece abandoned her currency, the drachma and introduced the euro from January 1, 2002; fifth, from 2002:01-2008:12 (the period of the common currency); and final, the entire period from 1974:01-2008:12. The first results (Table 1) show the social loss, Eq. 1, of Greece, which was $\mathrm{L}=3.243$ for the entire period and the worst was in 2001 ( $\mathrm{L}=17.510)$. The highest losses are due to inflation, interest rate and unemployment; the lowest loss (actually negative losses = benefits) is due to risk. Then, we started analyzing Greece and the Euro-zone data by looking and comparing their mean values, their natural logarithms, their growth and their standard deviations. The growth of GDP is higher in Greece than the EMU, the inflation rate, the money supply growth and the interest rates, too; The unemployment rate $(\overline{\mathrm{u}}=8.16 \%)$ in Greece is lower relative to EMU $\left(\overline{\mathbf{u}}^{*}=8.29 \%\right)$. The exports and imports of Greece have a high risk $\left(\sigma_{\dot{\mathrm{X}}}=350.72 \%\right)$. After the introduction of euro, Greece's unemployment has increased ( $\overline{\mathrm{u}}=9.55 \%)$, but trade has improved, inflation has declined, interest rates and consumption have also fallen, government spending has increased.

Next, we looked at the correlation coefficients $\left(\rho X, X^{*}\right)$ between Greece and the EMU macrovariables. The $\rho X, X^{*}$ is higher than +0.50 between $Y^{*}$ 
and $\mathrm{Y}, \mathrm{Y}^{*}$ and $\mathrm{P}, \mathrm{Y}^{*}$ and $\mathrm{M}, \mathrm{Y}^{*}$ and $\mathrm{w}, \mathrm{Y}^{*}$ and $\mathrm{C}, \mathrm{Y}^{*}$ and $\mathrm{M} 2 ; \mathrm{Y}^{*}$ and $\mathrm{u}$ have high negative correlation $\left(\rho_{\mathrm{y}}{ }^{*}, \mathrm{u}=-0.865\right)$. The same high positive correlation exists between $\mathrm{P}^{*}$ and $\mathrm{Y}, \mathrm{P}^{*}$ and $\mathrm{P}, \mathrm{P}^{*}$ and $\mathrm{M}, \mathrm{P}^{*}$ and $\mathrm{w}, \mathrm{P}^{*}$ and $\mathrm{u}, \mathrm{P}^{*}$ and $\mathrm{C}, \mathrm{P}^{*}$ and $\mathrm{G}, \mathrm{P}^{*}$ and $\mathrm{M} 2$. Interest rates have a negative correlation with most of the variables. These reveal a high interdependence between the two economies, the Greek and the EMU one (i.e., $\left.\rho y, y^{*}=0.990\right)$. At the same time, we test the causality between the variables in the two economies (Table $2 \mathrm{a}$ and $b$ ). The EMU $\mathrm{Y}^{*}$ causes $\mathrm{Y}, \mathrm{E}, \mathrm{P}, \mathrm{w}, \mathrm{X}, \mathrm{M}, \mathrm{G}$ and $\mathrm{M}$ 2. The exchange rate $\mathrm{E}$ causes $\mathrm{w}, \mathrm{i}_{\mathrm{TB}}, \mathrm{C}, \mathrm{X}$ and $\mathrm{P}_{\text {oil. }}$ Price of oil $\left(\mathrm{P}_{\mathrm{oil}}\right)$ causes $\mathrm{w}, \mathrm{CE}, \mathrm{M}^{\mathrm{s}}, \mathrm{X}$ and $\mathrm{i}_{\mathrm{GB}}$. The policy variables (G, M2 and i instruments) cause E, P, $\mathrm{X}, \mathrm{M}, \mathrm{u}$ and $\mathrm{P}_{\mathrm{oil}}$. The European unemployment and the high ECB rate cause unemployment in Greece.

The European income, prices, introduction of euro, high wages and money supply have caused an uncontrolled inflation in Greece. Then, the results from the Augmented Dickey-Fuller and Phillips-Perron unit root test for the variables of our model are not reported, here. The most of the series are not stationary. Also, the results of the cointegration tests of the equations of the model are not presented. Trace tests and maximum eigenvalue ones indicate that our equations are cointegrating (stationary).

Table 1: Components of the social loss [Eq. 1]

\begin{tabular}{|c|c|c|c|c|c|c|c|c|c|c|c|}
\hline & $\mathrm{Lu}$ & $\mathrm{Ld}$ & $\mathrm{Li}$ & $\mathrm{L} \pi$ & $\mathrm{Lq}$ & Ls & $\mathrm{Lm}^{\mathrm{s}}$ & Lta & Lbd & Lspi & $\mathrm{L}$ \\
\hline \multicolumn{12}{|c|}{$\begin{array}{l}\text { 1974:01-1980:12 } \\
\end{array}$} \\
\hline$\overline{\mathrm{X}}$ & - & - & - & 1.671 & 0.2220 & - & 0.8100 & -0.7040 & - & - & 1.9990 \\
\hline$\sigma \mathrm{X}$ & & & & 1.978 & 6.5900 & & 1.5010 & 35.3120 & & & 35.2760 \\
\hline \multicolumn{12}{|c|}{ 1981:01-1992:12 } \\
\hline$\overline{\mathrm{X}}$ & 0.638 & -0.6690 & 1.832 & 1.876 & 0.0180 & - & 0.3870 & 0.4560 & - & - & 4.5380 \\
\hline$\sigma \mathrm{X}$ & 0.181 & 0.3520 & 1.781 & 1.790 & 8.0070 & & 1.7300 & 43.7090 & & & 40.7440 \\
\hline \multicolumn{12}{|c|}{ 1981:01-2000:12 } \\
\hline$\overline{\mathrm{X}}$ & 0.840 & -0.5560 & 1.333 & 1.410 & 0.0240 & - & 0.2650 & 0.2280 & 0.9450 & -1.4790 & 3.0100 \\
\hline$\sigma \mathrm{X}$ & 0.303 & 0.3020 & 1.763 & 1.782 & 6.7610 & 1.628 & 36.5870 & 12.3690 & 12.6270 & 24.6240 & \\
\hline \multicolumn{12}{|c|}{ 2001:01-2001:12 } \\
\hline$\overline{\mathrm{X}}$ & 1.194 & -0.1970 & 0.333 & 0.333 & -0.0460 & - & 0.5080 & 1.2090 & 10.5290 & 3.6470 & 17.5100 \\
\hline$\sigma \mathrm{X}$ & 0.053 & 0.0740 & 1.524 & 1.524 & 2.1780 & & 1.0710 & 65.6350 & 44.3870 & 11.9580 & 66.2150 \\
\hline \multicolumn{12}{|c|}{ 2002:01-2008:12 } \\
\hline$\overline{\mathrm{X}}$ & 1.061 & -0.2090 & 0.363 & 0.363 & -0.1070 & - & 0.4000 & 0.0200 & -1.7450 & 1.0400 & 1.1860 \\
\hline$\sigma \mathrm{X}$ & 0.104 & 0.0790 & 1.392 & 1.392 & 2.1070 & & 1.0090 & 13.9620 & 17.7080 & 9.6360 & 26.5110 \\
\hline \multicolumn{12}{|c|}{ 1974:01-2008:12 } \\
\hline$\overline{\mathrm{X}}$ & 0.906 & -0.4400 & 1.038 & 1.225 & 0.0370 & - & 0.3230 & 0.0300 & 0.1060 & 0.0180 & 3.2430 \\
\hline$\sigma \mathrm{X}$ & 0.285 & 0.3000 & 1.719 & 1.807 & 6.0100 & & 1.4830 & 34.3320 & 21.2910 & 11.3480 & 32.7270 \\
\hline
\end{tabular}

Note: On January 1, 1981, Greece joined the EC; on January 1, 1993, the European integration took place (EU); on January 1, 1999, the EMU was established; on January 1, 2001, Greece joined the EMU and on January 1, 2002 the Euro-notes and coins were introduced. Lu: Loss to society due to unemployment; Ld: Loss due to risk; Li: Loss due to interest rate; L $\pi$ : Loss due to inflation; Lq: Loss due to production; Ls: Loss due to saving (no data available); Lms: Loss due to growth of money supply; Lta: Loss due to trade account growth; Lbd: Loss due to budget deficit; Lspi: Loss due to growth of the stock market; L: The total loss to society; w: 1/9; X: The mean value of the variable; $\sigma \mathrm{X}$ : The standard deviation. Source: International Financial Statistics (IMF) and Eurostat

Table 2a: Pairwise granger causality tests

\begin{tabular}{|c|c|c|c|c|c|c|c|c|c|c|c|c|c|c|}
\hline & $\mathrm{y}$ & $\mathrm{p}$ & $\mathrm{w}$ & ce & $\mathrm{s}$ & $\mathrm{u}$ & $\mathrm{m}^{\mathrm{s}}$ & $\mathrm{i}_{\mathrm{TB}}$ & $\mathrm{c}$ & g & $\mathrm{x}$ & $\mathrm{m}$ & $\mathrm{p}_{\text {oil }}$ & $\mathrm{i}_{\mathrm{GB}}$ \\
\hline$y \Rightarrow$ & - & $41.330^{* * * *}$ & $13.585^{* * *}$ & $25.312^{* * * *}$ & $3.414 * *$ & $4.075 * * * *$ & $7.202^{* * * *}$ & $3.897 * *$ & $10.180 * * *$ & $8.462 * * *$ & $9.520^{* * *}$ & $8.924 * * *$ & - & - \\
\hline$p \Rightarrow$ & $3.660^{* * *}$ & - & $18.742^{* * * *}$ & $24.686^{* * * *}$ & - & - & $13.284^{* * * *}$ & $3.670^{* *}$ & - & $4.601 * * *$ & $12.692 * * *$ & $8.232 * * *$ & - & - \\
\hline $\mathrm{w} \Rightarrow$ & - & $14.530^{* * *}$ & - & - & $3.486 * * *_{-}$ & $7.059^{* * * *}$ & - & - & $2.486^{*}$ & - & $7.551^{* * * *}$ & - & - & \\
\hline $\mathrm{ce} \Rightarrow$ & $2.764^{* * *}$ & - & $10.022^{* * * *}$ & - & $4.330^{* * * *}$ & $2.253^{* * * *}$ & $2.372 *$ & - & $6.752^{* * * *}$ & - & $4.354 * * * *$ & $7.102^{* * * *}$ & - & - \\
\hline $\mathrm{s} \Rightarrow$ & - & - & $7.611^{* * * *}$ & $3.595^{* * *}$ & - & - & - & $2.580^{*}$ & $3.336 * *$ & - & 3.260 ** & - & $2.446 *$ & - \\
\hline $\mathrm{u} \Rightarrow$ & - & $4.913^{* * *}$ & $9.856 * * *$ & $3.936^{* * * *}$ & $4.213 * * *_{-}$ & - & $4.503^{* * *}$ & - & - & - & - & $2.335 *$ & - & \\
\hline $\mathrm{m}^{\mathrm{s}} \Rightarrow$ & - & $40.450 * * *$ & $32.217 * * *$ & $15.533 * * *$ & $2.773 * *$ & 8.738 *** & - & - & - & $111.17 * * *$ & $12.089 * * *$ & $28.391 * * *$ & $2.868^{* * *}$ & $6.307 * * *$ \\
\hline $\mathrm{i}_{\mathrm{TB}} \Rightarrow$ & - & $3.697^{* * * *}$ & $2.885^{* *}$ & - & $2.684 * *$ & - & - & - & $2.248^{*}$ & - & - & - & $2.406^{*}$ & $3.928 * * *$ \\
\hline $\mathrm{i}_{\mathrm{GB}} \Rightarrow$ & - & $3.252 * * *$ & $6.449^{* * *}$ & - & - & - & - & - & $2.994 * *$ & - & - & $2.310^{*}$ & - & - \\
\hline$c \mathrm{i}_{\mathrm{TB}} \Rightarrow$ & $9.209^{* * *}$ & $4.329 * * *$ & $15.895 * * *$ & $28.967 * * *$ & $4.236 * * *_{-}$ & - & - & - & - & - & - & $6.438 * * *$ & - & \\
\hline $\mathrm{g} \mathrm{i}_{\mathrm{TB}} \Rightarrow$ & - & $30.220^{* * * *}$ & $13.232^{* * *}$ & $20.179 * * *$ & $3.805 * *$ & - & $10.303^{* * *}$ & $3.241^{* *}$ & - & - & $12.411^{* * * *}$ & $14.978^{* * *}$ & - & - \\
\hline $\mathrm{x} \mathrm{i}_{\mathrm{TB}} \Rightarrow$ & - & $7.228 * * *$ & $6.796^{* * * *}$ & $3.206^{* *}$ & - & - & $8.436^{* * * *}$ & - & - & $15.300 * * *$ & - & - & $3.832 * * *$ & $2.615^{* * *}$ \\
\hline $\mathrm{mi}_{\mathrm{TB}} \Rightarrow$ & - & $6.329 * * *$ & $14.631^{* * *}$ & $6.008^{* * * *}$ & - & - & $6.072^{* * * *}$ & - & - & $10.491 * * *$ & - & - & $2.181^{*}$ & $4.177 * * *$ \\
\hline $\mathrm{p}_{\text {oil }} \mathrm{i}_{\mathrm{TB}} \Rightarrow$ & - & - & $8.342 * * *$ & 4.001**** & - & - & $2.915^{* * *}$ & - & - & - & $3.762 * * * *$ & - & - & $2.426^{*}$ \\
\hline
\end{tabular}

Note: $\mathrm{x} \Rightarrow \mathrm{y}$ : $\mathrm{x}$ causes $\mathrm{y}$; Y: Income; E: Exchange rate; P: Price level, X: Exports; M: Imports; w: Wages and salaries; CE: Compensation of employees; u: Unemployment rate; S: Saving; C: Consumption; I: Investment; G: Government spending; T: Taxes; M2: Money supply; i iF $^{\circ}$ Federal funds rate; $\mathrm{i}_{\mathrm{TB}}$ : Treasury Bill rate; $\mathrm{i}_{\mathrm{GB}}$ Government bonds rate; $\overline{\mathrm{X}}$ : The mean value of the variable $\mathrm{X} ; \sigma \mathrm{X}$ : The standard deviation of $\mathrm{X}$; $\overline{\mathrm{X}}$ : The mean value of the $\ln \mathrm{X} ; \sigma_{\mathrm{x}}$ : The standard deviation of the $\ln \mathrm{X} ; \dot{\mathrm{x}}$ : The growth of $\mathrm{X}, \sigma_{\mathrm{x}}$ : The standard deviation of the growth of $\mathrm{X}$; $\mathrm{i}_{\mathrm{OND}}$ : Overnight deposit rate; $\mathrm{i}_{3 \mathrm{MDL}}: 3$ month deposit rate (LIBOR), an $\left(^{*}\right)$ : Denotes the foreign country (Euro-zone); Source: http://www.economagic.com, http://www.imfstatistics.org and Eurostat, Year Book, various issues 
Am. J. of Economics and Business Administration 1 (2) 57-78, 2009

Table 2b: Pairwise granger causality tests

\begin{tabular}{|c|c|c|c|c|c|c|c|c|c|c|c|c|c|c|}
\hline & $\mathrm{y}$ & $\mathrm{p}$ & $\mathrm{w}$ & ce & $\mathrm{s}$ & $\mathrm{u}$ & $\mathrm{m}^{\mathrm{s}}$ & $i_{\mathrm{TB}}$ & $\mathrm{i}_{\mathrm{GB}}$ & $\mathrm{c}$ & g & $\mathrm{x}$ & $\mathrm{m}$ & $\mathrm{p}_{\mathrm{oil}}$ \\
\hline $\mathrm{y}^{*} \Rightarrow$ & $2.745^{* *}$ & 21.130 *** & $11.773 * * *$ & $15.806^{* * *}$ & $4.119 * * *$ & - & $12.336^{* * * *}$ & - & - & - & $8.678 * * *$ & $6.280 * * *$ & $6.728 * * *$ & - \\
\hline $\mathrm{p}^{*} \Rightarrow$ & - & $16.951 * * *$ & $14.878 * * *$ & $23.191 * * *$ & - & $7.867 * * *$ & - & - & - & - & $2.628 *$ & $4.347 * * *$ & $7.316^{* * * *}$ & - \\
\hline $\mathrm{w}^{*} \Rightarrow$ & $26.721 * * *$ & $26.972 * * *$ & $16.256^{* * *}$ & $31.057 * * *$ & $4.156 * * *$ & $4.543^{* * *}$ & $9.352 * * *$ & - & $3.020^{* *}$ & - & $7.166 * * *$ & $4.856^{* * *}$ & $8.985 * * *$ & - \\
\hline $\mathrm{u}^{*} \Rightarrow$ & - & - & - & - & - & - & - & - & - & - & - & - & - & - \\
\hline $\mathrm{m}^{* \mathrm{~s}} \Rightarrow$ & - & $28.696^{* * * *}$ & $27.823 * * *$ & $17.581 * * *$ & $2.751 * *$ & $4.412 * * *$ & - & - & $4.906 * * *$ & $3.189 * *$ & $42.137 * * *$ & $5.279 * * *$ & $8.628 * * *$ & $2.609 *$ \\
\hline$c^{*} \Rightarrow$ & $4.404^{* * *}$ & $18.660^{* * *}$ & $12.479 * * *$ & $16.141^{* * *}$ & $3.530 * *$ & - & $14.493^{* * *}$ & - & - & - & $8.560 * * *$ & $6.579 * * *$ & $7.912 * * *$ & $2.358^{*}$ \\
\hline $\mathrm{i}^{*} \mathrm{OND} \Rightarrow$ & - & - & - & - & - & $4.371 * * *$ & - & - & - & - & $2.637 *$ & - & - & - \\
\hline $\mathrm{i}_{\mathrm{GB}}^{*} \Rightarrow$ & - & - & $4.101 * * *$ & - & - & - & - & - & - & $3.369 * *$ & - & - & - & $2.683 * *$ \\
\hline $\mathrm{g}^{*} \Rightarrow$ & $10.397 * * *$ & 19.511 *** & $15.239 * * *$ & - & $4.206 * * *$ & - & $10.152 * * *$ & - & - & - & $6.441 * * *$ & $4.947 * * *$ & $7.580 * * *$ & - \\
\hline $\mathrm{x}^{*} \Rightarrow$ & - & $2.618^{*}$ & $4.955 * * *$ & $2.708 * * *$ & - & $3.154 * *$ & - & - & - & - & - & - & - & - \\
\hline
\end{tabular}

Note: Table 1 and 2a; Source: Table 1 and $2 \mathrm{a}$

Table 3: Least squares estimations of the model's AS: Eq. 2 and 3

\begin{tabular}{|c|c|c|c|c|c|c|c|}
\hline Variables & $\mathrm{y}$ & $\mathrm{y}$ & $\mathrm{y}$ & $\mathrm{y}$ & & $y^{*}$ & $\mathrm{y}^{*}$ \\
\hline$\alpha_{0}$ & $-26.673 * * *(2.387)$ & $-23.201 * * *(2.114)$ & $-20.998 * * *(2.035)$ & $-21.554 * * *(2.283)$ & $\alpha_{0}$ & $0.546(0.333)$ & $88.176(12.384)$ \\
\hline $\mathrm{p}$ & $3.746^{* * *}(0.162)$ & $3.267 * * *(0.167)$ & $3.431 * * *(0.171)$ & $2.897 * * *(0.205)$ & $\mathrm{p}^{*}$ & $1.499 * * *(0.152)$ & $-0.213 *(0.122)$ \\
\hline w & $0.028 * \operatorname{ce}(0.015)$ & $0.137 * * * \mathrm{w}(0.025)$ & $-0.023 * * *$ ce $(0.009)$ & $0.203 * * *(0.030)$ & $\mathrm{w}^{*}$ & $0.259 * * *(0.093)$ & $1.271 * * *(0.087)$ \\
\hline$e+p *-p$ & $18.601 * * *(1.666)$ & $16.962 * * *(1.460)$ & $14.719 * * *(1.312)$ & $15.921 * * *(1.501)$ & $e+p^{*}-p$ & $1.106 * *(0.457)$ & $0.009(0.163)$ \\
\hline $\mathrm{p}_{\mathrm{oil}}$ & $-0.022 * *(0.009)$ & $-0.017 * *(0.008)$ & $-0.022 *(0.013)$ & $-0.008(0.013)$ & $p_{\text {oil }}$ & $0.004(0.005)$ & $-0.001(0.004)$ \\
\hline u & $0.011 * * *(0.003)$ & $0.008 * * *(0.003)$ & $0.002(0.003)$ & $0.002(0.003)$ & $\mathrm{u}^{*}$ & $-0.016 * * *(0.002)$ & $-0.008 * *(0.004)$ \\
\hline $\mathrm{AR}(1)$ & - & - & - & $0.567 * * *(0.093)$ & $\mathrm{AR}(1)$ & - & $0.999 * * *(0.013)$ \\
\hline MA (1) & - & - & $0.974 * * *(0.012)$ & - & MA (1) & - & - \\
\hline $\mathrm{R}^{2}$ & 0.993 & 0.995 & 0.995 & 0.996 & $\mathrm{R}^{2}$ & 0.995 & 0.999 \\
\hline SER & 0.015 & 0.013 & 0.013 & 0.011 & SER & 0.008 & 0.003 \\
\hline $\mathrm{D}-\mathrm{W}$ & 1.305 & 1.063 & 2.182 & 2.006 & $\mathrm{D}-\mathrm{W}$ & 0.825 & 2.150 \\
\hline $\mathrm{F}$ & 2775.910 & 3560.780 & 3132.700 & 3872.430 & $\mathrm{~F}$ & 4216.760 & 22783.070 \\
\hline $\mathrm{N}$ & 99.000 & 99.000 & 99.000 & 98.000 & $\mathrm{~N}$ & 111.000 & 110.000 \\
\hline
\end{tabular}

Note: Table 1 and 2a. y: ln of gross domestic product; p: ln of CPI; w: In of wages; ce: ln of compensation of employees; e+p*-p: ln of TOT; $\mathrm{p}_{\text {oil }}$ : In of price of oil; u: Unemployment rate; e: ln of spot exchange rate; ***: Significant at the 1\% level; **: Significant at the 5\% level; *: Significant at the $10 \%$ level, Source: Table 1

Table 4: Least squares estimations of the model's AS: Eq. 4 and 5

\begin{tabular}{|c|c|c|c|c|c|c|c|}
\hline Variables & $\mathrm{p}$ & $\mathrm{p}$ & $\mathrm{p}$ & & $\mathrm{p}^{*}$ & $\mathrm{p}^{*}$ & $\mathrm{p}^{*}$ \\
\hline$\alpha_{0}$ & $\begin{array}{l}8.173 * * * \\
(0.304)\end{array}$ & $\begin{array}{l}8.322 \text { *** } \\
(0.270)\end{array}$ & $\begin{array}{l}7.591 \text { *** } \\
(0.326)\end{array}$ & $\alpha_{0}$ & $\begin{array}{l}0.394 * * * \\
(0.151)\end{array}$ & $\begin{array}{l}0.631 \text { *** } \\
(0.197)\end{array}$ & $\begin{array}{l}1.225 * * * \\
(0.276)\end{array}$ \\
\hline $\mathrm{y}$ & $\begin{array}{l}0.227 * * * \\
(0.010)\end{array}$ & $\begin{array}{l}0.205^{* * *} \\
(0.013)\end{array}$ & $\begin{array}{l}0.238^{* * * *} \\
(0.014)\end{array}$ & $y^{*}$ & $\begin{array}{l}0.320 * * * \\
(0.033)\end{array}$ & $\begin{array}{l}0.215^{* * *} * \\
(0.060)\end{array}$ & $\begin{array}{c}0.057 \\
(0.078)\end{array}$ \\
\hline w & $\begin{array}{l}-0.007 * \\
(0.004)\end{array}$ & $\begin{array}{l}0.010 * * \\
(0.004)\end{array}$ & $\begin{array}{l}0.011^{* * *} \\
(0.003)\end{array}$ & $\mathrm{w}^{*}$ & $\begin{array}{l}0.202 * * * \\
(0.040)\end{array}$ & $\begin{array}{l}0.297 * * * \\
(0.071)\end{array}$ & $\begin{array}{l}0.435 * * * \\
(0.083)\end{array}$ \\
\hline$e+p *-p$ & $\begin{array}{l}-5.657 * * * \\
(0.225)\end{array}$ & $\begin{array}{l}-5.725 * * * \\
(0.193)\end{array}$ & $\begin{array}{l}-5.291 * * * \\
(0.228)\end{array}$ & $e+p^{*}-p$ & $\begin{array}{l}-0.849 * * * \\
(0.201)\end{array}$ & $\begin{array}{l}-0.957 * * * \\
(0.187)\end{array}$ & $\begin{array}{l}-0.953 * * * \\
(0.180)\end{array}$ \\
\hline $\mathrm{p}_{\text {oil }}$ & $\begin{array}{l}0.011 * * * \\
(0.002)\end{array}$ & $\begin{array}{l}0.019 * * * \\
(0.004)\end{array}$ & $\begin{array}{l}0.015^{* * * *} \\
(0.003)\end{array}$ & $\mathrm{p}_{\mathrm{oil}}$ & $\begin{array}{l}0.008 * * * \\
(0.002)\end{array}$ & $\begin{array}{l}0.013 * * * \\
(0.003)\end{array}$ & $\begin{array}{l}0.013 \text { *** } \\
(0.003)\end{array}$ \\
\hline $\mathrm{u}$ & $\begin{array}{l}-0.004 * * * \\
(0.001)\end{array}$ & $\begin{array}{l}-0.002 \\
(0.001)\end{array}$ & $\begin{array}{l}-0.002 * * \\
(0.001)\end{array}$ & $\mathrm{u}^{*}$ & $\begin{array}{l}0.004 * * * \\
(0.001)\end{array}$ & $\begin{array}{c}0.001 \\
(0.002)\end{array}$ & $\begin{array}{l}-0.005^{*} \\
(0.003)\end{array}$ \\
\hline $\mathrm{e}$ & - & - & $\begin{array}{l}-0.014 \\
(0.009)\end{array}$ & $\mathrm{e}$ & - & - & $\begin{array}{l}0.032^{* * *} \\
(0.011)\end{array}$ \\
\hline AR (1) & - & $\begin{array}{l}0.710^{* * * *} \\
(0.089)\end{array}$ & - & $\mathrm{AR}(1)$ & - & $\begin{array}{l}0.502 * * * \\
(0.092)\end{array}$ & $\begin{array}{l}0.525^{* * *} \\
(0.087)\end{array}$ \\
\hline MA (1) & - & - & $\begin{array}{l}0.7834 * * * \\
(0.076)\end{array}$ & MA (1) & - & - & - \\
\hline $\mathrm{R}^{2}$ & 0.998 & 0.998 & 0.998 & $\mathrm{R}^{2}$ & 0.996 & 0.997 & 0.997 \\
\hline SER & 0.004 & 0.003 & 0.003 & SER & 0.004 & 0.003 & 0.003 \\
\hline D-W & 1.226 & 2.043 & 1.977 & D-W & 1.187 & 2.042 & 1.984 \\
\hline $\mathrm{F}$ & 8844.470 & 8786.260 & 7845.380 & $\mathrm{~F}$ & 5501.880 & 5390.470 & 4940.500 \\
\hline $\mathrm{N}$ & 99.000 & 98.000 & 99.000 & $\mathrm{~N}$ & 111.000 & 110.000 & 110.000 \\
\hline
\end{tabular}

Note: Table 1 and 2a. y: ln of gross domestic product; p: $\ln$ of CPI; w: $\ln$ of wages; ce: $\ln$ of compensation of employees; e+p*-p: ln of TOT; $\mathrm{p}_{\text {oil }}$ : In of price of oil; $\mathrm{u}$ : Unemployment rate; ***: Significant at the 1\% level; ***: Significant at the 5\% level; $*$ : Significant at the $10 \%$ level; Source: Table 1

Further, Table 3-7 show the least squares estimations of the aggregate supplies, aggregate demands, money market equilibrium and the balance of payments in Greece and EMU. The price of oil is affecting negatively production and positively inflation. The coefficients of $y$ and $y^{*}$ are highly 


\section{Am. J. of Economics and Business Administration 1 (2) 57-78, 2009}

significant and reveal the interdependence between the two economies. The appreciation of euro increases the demand for money and deteriorates the trade balance, as has been hypothesized. Table 8 shows the Vector Autoregression Estimates of the three (3) public policy objective variables $(y, p, u)$ for Greece and EMU and the effectiveness of policy instruments $\left(\mathrm{i}^{*}\right.$ OND $\left., \mathrm{M}^{\mathrm{s}}, \mathrm{G}\right) \quad$ on the ultimate objective variables. The income (y) is affected positively by G. Prices (CPI) are affected positively by $\mathrm{M}^{\mathrm{s}}$ and negatively by $\mathrm{i}^{*}$ OND. The unemployment rate is not affected by any policy instruments. The unemployment rate in Greece is structural, due to integration, loss of manufacturing and the uncontrolled illegal migration.

Table 5: Least squares estimations of the model's AD: Eq. 6-9

\begin{tabular}{|c|c|c|c|c|c|c|c|c|c|}
\hline Variables & $\mathrm{y}$ & $\mathrm{y}$ & $\mathrm{p}$ & $\mathrm{p}$ & & $\mathrm{y}^{*}$ & $y^{*}$ & $\mathrm{p}^{*}$ & $\mathrm{p}^{*}$ \\
\hline$\alpha_{0}$ & $\begin{array}{l}7.976^{* * * *} \\
(1.276)\end{array}$ & $\begin{array}{l}\text { 4.301** } \\
(1.691)\end{array}$ & $\begin{array}{l}8.552 * * * \\
(0.592)\end{array}$ & $\begin{array}{l}7.370 * * * \\
(0.590)\end{array}$ & $\alpha_{0}$ & $\begin{array}{c}0.039 \\
(0.501)\end{array}$ & $\begin{array}{l}0.977 * * \\
(0.486)\end{array}$ & $\begin{array}{l}2.658^{* * *} \\
(0.308)\end{array}$ & $\begin{array}{l}2.899 * * * \\
(0.259)\end{array}$ \\
\hline $\mathrm{p}$ & $\begin{array}{l}-0.079 \\
(0.148)\end{array}$ & $\begin{array}{l}-0.038 \text { y } \\
(0.140)\end{array}$ & $\begin{array}{l}-0.039 y \\
(0.073)\end{array}$ & $\begin{array}{c}0.078 \\
(0.070)\end{array}$ & $\mathrm{p}^{*}$ & $\begin{array}{l}-0.219^{*} \\
(0.124)\end{array}$ & $\begin{array}{l}-0.092 y^{*} \\
(0.087)\end{array}$ & $\begin{array}{l}-0.149^{*} \\
(0.084)\end{array}$ & $\begin{array}{l}-0.073 \\
(0.091)\end{array}$ \\
\hline$E+p *-p$ & $\begin{array}{l}-0.507 \\
(0.835)\end{array}$ & $\begin{array}{l}-0.302 \\
(0.754)\end{array}$ & $\begin{array}{l}-5.186^{* * * *} \\
(0.231)\end{array}$ & $\begin{array}{l}-4.950 * * * \\
(0.187)\end{array}$ & $e+p^{*}-p$ & $\begin{array}{c}0.330 \\
(0.295)\end{array}$ & $\begin{array}{l}-0.153 \\
(0.141)\end{array}$ & $\begin{array}{l}-0.553 * * \\
(0.238)\end{array}$ & $\begin{array}{l}-0.110 \\
(0.175)\end{array}$ \\
\hline $\mathrm{m}^{\mathrm{s}}$ & $\begin{array}{l}-0.113 * * \\
(0.050)\end{array}$ & $\begin{array}{l}-0.107 * * \\
(0.051)\end{array}$ & $\begin{array}{l}0.162 * * * \\
(0.032)\end{array}$ & $\begin{array}{l}0.256^{* * * *} \\
(0.025)\end{array}$ & $\mathrm{m}^{* \mathrm{~s}}$ & $\begin{array}{l}0.156^{* * * *} \\
(0.043)\end{array}$ & $\begin{array}{c}0.055 \\
(0.035)\end{array}$ & $\begin{array}{l}0.191 \text { *** } \\
(0.032)\end{array}$ & $\begin{array}{l}0.295 \text { *** } \\
(0.027)\end{array}$ \\
\hline c & $\begin{array}{l}1.106^{* * *} \\
(0.037)\end{array}$ & $\begin{array}{l}0.627 * * * \\
(0.065)\end{array}$ & $\begin{array}{l}0.189 * * \\
(0.083)\end{array}$ & $\begin{array}{c}0.023 \\
(0.075)\end{array}$ & $\mathrm{c}^{*}$ & $\begin{array}{l}1.062 * * * \\
(0.093)\end{array}$ & $\begin{array}{c}0.454 \\
(0.108)\end{array}$ & $\begin{array}{c}0.169 \\
(0.118)\end{array}$ & $\begin{array}{l}-0.213 * \\
(0.120)\end{array}$ \\
\hline $\mathrm{g}$ & $\begin{array}{l}0.132 * * * \\
(0.021)\end{array}$ & $\begin{array}{c}0.009 \\
(0.035)\end{array}$ & $\begin{array}{c}0.019 \\
(0.017)\end{array}$ & $\begin{array}{l}-0.004 \\
(0.022)\end{array}$ & $\mathrm{g}^{*}$ & $\begin{array}{l}-0.154 * * \\
(0.061)\end{array}$ & $\begin{array}{l}0.259 * * * \\
(0.072)\end{array}$ & $\begin{array}{l}-0.012 \\
(0.052)\end{array}$ & $\begin{array}{c}0.038 \\
(0.069)\end{array}$ \\
\hline $\mathrm{x}$ & $\begin{array}{c}0.003 \\
(0.005)\end{array}$ & $\begin{array}{l}0.004 * \\
(0.003)\end{array}$ & $\begin{array}{c}0.005 \\
(0.003)\end{array}$ & $\begin{array}{c}0.002 \\
(0.002)\end{array}$ & $\mathrm{x}^{*}$ & $\begin{array}{c}0.024 \\
(0.027)\end{array}$ & $\begin{array}{c}0.001 \\
(0.010)\end{array}$ & $\begin{array}{l}-0.034 \\
(0.022)\end{array}$ & $\begin{array}{l}-0.003 \\
(0.010)\end{array}$ \\
\hline $\mathrm{m}$ & $\begin{array}{c}0.006 \\
(0.004)\end{array}$ & $\begin{array}{l}-0.004 * \\
(0.002)\end{array}$ & $\begin{array}{l}-0.005^{*} \\
(0.003)\end{array}$ & $\begin{array}{l}-0.002 \\
(0.002)\end{array}$ & $\mathrm{m}^{*}$ & $\begin{array}{l}-0.028 \\
(0.027)\end{array}$ & $\begin{array}{l}-0.007 \\
(0.010)\end{array}$ & $\begin{array}{c}0.033 \\
(0.022)\end{array}$ & $\begin{array}{c}0.005 \\
(0.010)\end{array}$ \\
\hline $\mathrm{Y}^{*}$ & $\begin{array}{l}-0.087 \\
(0.072)\end{array}$ & $\begin{array}{l}0.610^{* * * *} \\
(0.133)\end{array}$ & $\begin{array}{l}-0.051 \\
(0.051)\end{array}$ & $\begin{array}{l}-0.099 \\
(0.064)\end{array}$ & $\mathrm{y}$ & $\begin{array}{c}0.039 \\
(0.036)\end{array}$ & $\begin{array}{l}0.207 * * * \\
(0.048)\end{array}$ & $\begin{array}{l}0.099 * * * \\
(0.028)\end{array}$ & $\begin{array}{l}0.121 \text { *** } \\
(0.040)\end{array}$ \\
\hline AR (1) & - & $\begin{array}{l}0.984 * * * \\
(0.013)\end{array}$ & - & $\begin{array}{l}0.539 * * * \\
(0.120)\end{array}$ & AR (1) & - & $\begin{array}{l}0.967 * * * \\
(0.022)\end{array}$ & - & $\begin{array}{l}0.609 * * * \\
(0.103)\end{array}$ \\
\hline MA (1) & - & - & - & $\begin{array}{l}0.372 * * * \\
(0.142)\end{array}$ & MA (1) & - & - & - & $\begin{array}{l}0.372 * * * \\
(0.129)\end{array}$ \\
\hline $\mathrm{R}^{2}$ & 0.999 & 0.999 & 0.998 & 0.999 & $\mathrm{R}^{2}$ & 0.998 & 0.999 & 0.996 & 0.998 \\
\hline SER & 0.005 & 0.003 & 0.004 & 0.003 & SER & 0.005 & 0.002 & 0.004 & 0.003 \\
\hline D-W & 0.841 & 1.971 & 0.755 & 1.855 & $\mathrm{D}-\mathrm{W}$ & 0.534 & 2.104 & 0.671 & 1.873 \\
\hline $\mathrm{F}$ & 16121.050 & 30709.56 & 6397.270 & 9512.570 & F & 6254.520 & 21855.880 & 2615.100 & 4448.170 \\
\hline $\mathrm{N}$ & 101.000 & 100.000 & 101.000 & 100.000 & $\mathrm{~N}$ & 102.000 & 101.000 & 102.000 & 101.000 \\
\hline
\end{tabular}

Note: Table 1 and 2a. $y$ : ln of gross domestic product; $p$ : $\ln$ of CPI; $w: \ln$ of wages; ce: ln of compensation of employees; e+p*+p: ln of TOT; $p_{\text {oil }}$ : ln of price of oil; u: Unemployment rate; ***: Significant at the $1 \%$ level; **: Significant at the 5\% level; *: Significant at the $10 \%$ level. Source: Table 1

Table 6: Least squares estimations of the model's LM curve: Eq. 10-13

\begin{tabular}{|c|c|c|c|c|c|c|c|c|c|c|c|}
\hline \multicolumn{2}{|c|}{ Variables $\mathrm{m}^{\mathrm{s}}-\mathrm{p}$} & \multirow{2}{*}{$\begin{array}{l}\mathrm{m}^{\mathrm{s}}-\mathrm{p} \\
-0.641 \\
(0.427)\end{array}$} & \multirow{2}{*}{$\begin{array}{l}\mathrm{m}^{\mathrm{s}}-\mathrm{p} \\
-0.955^{* * *} \\
(0.351)\end{array}$} & \multirow{2}{*}{$\begin{array}{l}\mathrm{i}_{\mathrm{TB}} \\
-61.810^{* * *} \\
(20.839)\end{array}$} & \multirow{2}{*}{$\begin{array}{l}\mathrm{i}_{\mathrm{GB}} \\
-63.332 * \\
(33.435)\end{array}$} & \multirow[b]{2}{*}{$\alpha_{0}$} & \multirow{2}{*}{$\begin{array}{l}\mathrm{m}^{*} \mathrm{~s}-\mathrm{p}^{*} \\
-3.751 * * * \\
(0.125)\end{array}$} & \multirow{2}{*}{$\begin{array}{l}\mathrm{m}^{* \mathrm{~s}}-\mathrm{p}^{*} \\
-3.878^{* * *} \\
(0.272)\end{array}$} & \multirow{2}{*}{$\begin{array}{l}\mathrm{m}^{* \mathrm{~s}}-\mathrm{p}^{*} \\
-3.861 * * * \\
(0.279)\end{array}$} & \multirow{2}{*}{$\begin{array}{c}\mathrm{i}^{*} \text { OND } \\
-43.181 \\
(33.527)\end{array}$} & \multirow{2}{*}{$\begin{array}{l}\mathrm{i}_{\mathrm{GB}}^{*} \\
-98.219 * * \\
(46.023)\end{array}$} \\
\hline$\alpha_{0}$ & $\begin{array}{l}-1.546^{* * * *} \\
(0.194)\end{array}$ & & & & & & & & & & \\
\hline $\mathrm{y}$ & $\begin{array}{l}0.556^{* * * *} \\
(0.020)\end{array}$ & $\begin{array}{l}0.462 * * * \\
(0.045)\end{array}$ & $\begin{array}{l}0.493 * * * \\
(0.037)\end{array}$ & $\begin{array}{c}2.306 \\
(1.513)\end{array}$ & $\begin{array}{l}5.968 * * * \\
(2.057)\end{array}$ & $y^{*}$ & $\begin{array}{l}1.011 \text { *** } \\
(0.017)\end{array}$ & $\begin{array}{l}1.029 * * * \\
(0.037)\end{array}$ & $\begin{array}{l}1.029 * * * \\
(0.037)\end{array}$ & $\begin{array}{c}2.983 \\
(2.273)\end{array}$ & $\begin{array}{l}7.626 \text { **** } \\
(2.471)\end{array}$ \\
\hline $\mathrm{i}_{\mathrm{TB}}$ & $\begin{array}{l}0.014 * * * \\
(0.001)\end{array}$ & $\begin{array}{l}0.013 * * * \mathrm{i}^{*} \mathrm{OND} \\
(0.003)\end{array}$ & $\begin{array}{l}0.017 * * * \\
(0.003)\end{array}$ & $\begin{array}{c}\mathrm{m}^{\mathrm{s}} 5.105 * * * \\
(1.906)\end{array}$ & $\begin{array}{l}-0.453 \\
(2.601)\end{array}$ & $i^{*}$ OND & $\begin{array}{l}0.003 * * \\
(0.001)\end{array}$ & $\begin{array}{l}0.001 \mathrm{i}_{\mathrm{GB}}^{*} \\
(0.003)\end{array}$ & $\begin{array}{l}-0.004 \mathrm{~m}^{* \mathrm{~s}} \\
(0.004)\end{array}$ & $\begin{array}{l}-1.238 \\
(2.035)\end{array}$ & $\begin{array}{l}-0.673 \\
(2.288)\end{array}$ \\
\hline $\mathrm{e}$ & $\begin{array}{l}0.017 \\
(0.021) \\
-\end{array}$ & $\begin{array}{l}0.106 * * \\
(0.041) \\
-\end{array}$ & $\begin{array}{l}0.091^{* * *} \\
(0.037) \\
-p\end{array}$ & $\begin{array}{l}-1.688^{* * *} \\
(0.768) \\
-0.320 \\
(1.755)\end{array}$ & $\begin{array}{c}-0.171 \\
(0.772) \\
2.581 \\
(1.902)\end{array}$ & $\mathrm{e}$ & $\begin{array}{l}0.137 * * * \\
(0.012) \\
-\end{array}$ & $\begin{array}{c}0.118 \\
(0.024) \\
-\end{array}$ & $\begin{array}{l}0.105 * * * \\
(0.024) \\
-\mathrm{p}^{*}\end{array}$ & $\begin{array}{c}-0.481 \\
(0.608) \\
7.258 \\
(5.302)\end{array}$ & $\begin{array}{c}-1.281 * * \\
(0.658) \\
9.981 * \\
(5.919)\end{array}$ \\
\hline AR (1) & - & $\begin{array}{l}0.737 * * * \\
(0.072)\end{array}$ & $\begin{array}{l}0.642 * * * \\
(0.073)\end{array}$ & $\begin{array}{l}0.946^{* * * *} \\
(0.014)\end{array}$ & $\begin{array}{l}0.975^{* * * *} \\
(0.014)\end{array}$ & AR (1) & - & $\begin{array}{l}-0.652 \text { *** } \\
(0.073)\end{array}$ & $\begin{array}{l}0.688^{* * * *} \\
(0.077)\end{array}$ & $\begin{array}{l}0.984 \text { *** } \\
(0.016)\end{array}$ & $\begin{array}{l}0.993 \text { *** } \\
(0.012)\end{array}$ \\
\hline MA (1) & - & - & - & $\begin{array}{l}0.200^{* * *} \\
(0.106)\end{array}$ & $\begin{array}{l}-0.089 \\
(0.107)\end{array}$ & MA (1) & -- & - & - & $\begin{array}{c}0.138 \\
(0.099)\end{array}$ & $\begin{array}{l}0.231 * * \\
(0.099)\end{array}$ \\
\hline $\mathrm{R}^{2}$ & 0.983 & 0.990 & 0.990 & 0.985 & 0.930 & $\mathrm{R}^{2}$ & 0.994 & 0.997 & 0.997 & 0.977 & 0.947 \\
\hline SER & 0.014 & 0.010 & 0.010 & 0.161 & 0.176 & SER & 0.011 & 0.008 & 0.008 & 0.143 & 0.151 \\
\hline D-W & 0.699 & 1.891 & 1.854 & 1.923 & 2.010 & D-W & 0.705 & 2.047 & 2.077 & 1.899 & 1.956 \\
\hline $\mathrm{F}$ & 1863.740 & 2463.320 & 2447.570 & 1004.750 & 204.330 & $\mathrm{~F}$ & 6079.300 & 714.670 & 7778.590 & 734.580 & 315.080 \\
\hline $\mathrm{N}$ & 102.000 & 101.000 & 101.000 & 101.000 & 99.000 & $\mathrm{~N}$ & 114.000 & 113.000 & 113.000 & 113.000 & 113.000 \\
\hline
\end{tabular}


Am. J. of Economics and Business Administration 1 (2) 57-78, 2009

Table 7: Least squares estimations of the model's BP: Eq. 14-17

\begin{tabular}{|c|c|c|c|c|c|c|c|c|}
\hline Variables & es $x-m$ & $\mathrm{x}-\mathrm{m}$ & $\mathrm{x}$ & $\mathrm{m}$ & $\mathrm{i}_{\mathrm{TB}}$ & $\mathrm{x}^{*}-\mathrm{m} *$ & $\mathrm{x}^{*}$ & $\mathrm{i}^{*}$ OND \\
\hline$\alpha_{0}$ & $-5.321 *(2.923)$ & $-4.923 * *(2.453)$ & $-1.908(3.194)$ & $3.255(3.145)$ & $-55.895 * * *(16.383)$ & $0.751^{* *}(0.383)$ & $-42.582 *(22.569)$ & $-12.222(13.435)$ \\
\hline $\mathrm{y}$ & $0.415(0.734)$ & $0.248(0.609)$ & $-0.146(0.798)$ & $-0.579(0.782)$ & $-2.410(3.323)$ & $-0.124(0.095)$ & $-0.986(4.089)$ & $-8.760 * * *(2.776)$ \\
\hline$y^{*}$ & $0.031(1.011)$ & $0.188(0.820)$ & $1.338(1.121)$ & $1.351(1.074)$ & $10.744 * *(5.289)$ & $0.063(0.128)$ & $7.582(6.943)$ & $13.014 * * *(4.842)$ \\
\hline $\mathrm{i}_{\mathrm{TB}}-\mathrm{i}^{*}{ }_{\mathrm{OND}}$ & $0.086^{* * * *}(0.019)$ & $0.086^{* * *}(0.016)$ & $0.089 * * *(0.023)$ & $0.006(0.022) \mathrm{i}_{\text {OND }}^{*}$ & D $0.381 * * *(0.144) \mathrm{i}_{\mathrm{TB}}$ & $-\mathrm{i}^{*}{ }_{\mathrm{OND}}-0.001(0.003)$ & $0.304 * * *(0.113) \mathrm{i}^{\mathrm{T}}$ & ${ }^{\mathrm{TB}} 0.455^{*} * *(0.077)$ \\
\hline$e+p^{*}-p$ & $-0.082(1.587)$ & $-0.671(1.440)$ & $-5.114 * * *(1.577)$ & $-5.165 * * *(1.708)$ & $-0.336(1.877)$ & $-0.181(0.218)$ & $-2.386(2.386)$ & $0.230(1.684)$ \\
\hline e & $-0.685^{* * *}(0.230)$ & $-0.688 * * *(0.188)$ & $0.517 * *(0.255)$ & $1.176^{* * *}(0.246)$ & $-0.995(0.702)$ & $0.028(0.030)$ & $-0.036(0.883)$ & $0.050(0.624)$ \\
\hline AR (1) & - & $-0.232 * *(0.102)$ & $0.150(0.102)$ & $0.012(0.106)$ & $0.912 * * *(0.024)$ & $-0.121(0.102)$ & $0.915 * * *(0.044)$ & $0.847 * * *(0.030)$ \\
\hline MA (1) & - & - & - & - & - & - & - & - \\
\hline $\mathrm{R}^{2}$ & 0.288 & 0.295 & 0.887 & 0.889 & 0.984 & 0.151 & 0.964 & 0.977 \\
\hline SER & 0.127 & 0.124 & 0.121 & 0.132 & 0.164 & 0.018 & 0.211 & 0.147 \\
\hline D-W & 2.437 & 2.011 & 1.979 & 2.011 & 1.714 & 2.008 & 1.738 & 1.952 \\
\hline $\mathrm{F}$ & 7.680 & 6.470 & 121.710 & 123.640 & 966.070 & 2.780 & 423.730 & 671.260 \\
\hline $\mathrm{N}$ & 101.000 & 100.000 & 100.000 & 100.000 & 101.000 & 101.000 & 101.000 & 101.000 \\
\hline
\end{tabular}

Note: Table 1 and 2a. y: ln of gross domestic product, $\mathrm{p}$ : $\ln$ of CPI, w: $\ln$ of wages, ce: $\ln$ of compensation of employees, e+p*-p: $\ln$ of TOT, $\mathrm{p}_{\text {oil }}$ : In of price of oil, u: Unemployment rate, ***: Significant at the 1\% level, **: Significant at the 5\% level, *: Significant at the $10 \%$ level. Source: Table 1.

Table 8: Vector auto-regression estimates for Greece and Euro-zone

\begin{tabular}{|c|c|c|c|c|c|c|c|}
\hline Variables & $\mathrm{y}$ & $\mathrm{p}$ & $\mathrm{u}$ & & $\mathrm{y}^{*}$ & $\mathrm{p}^{*}$ & $\mathrm{u}^{*}$ \\
\hline$\alpha_{0}$ & $\begin{array}{c}0.218 \\
(0.220)\end{array}$ & $\begin{array}{l}0.593 * * * \\
(0.198)\end{array}$ & $\begin{array}{c}19.539 * \\
(10.234)\end{array}$ & $\alpha_{0}$ & $\begin{array}{l}0.933 * * * \\
(0.231)\end{array}$ & $\begin{array}{c}0.090 \\
(0.124)\end{array}$ & $\begin{array}{l}-3.278 \\
(4.094)\end{array}$ \\
\hline $\mathrm{y}_{\mathrm{t}-1}$ & $\begin{array}{l}0.585 * * * \\
(0.092)\end{array}$ & $\begin{array}{c}0.018 \\
(0.083)\end{array}$ & $\begin{array}{c}0.915 \\
(4.295)\end{array}$ & $\mathrm{y}_{\mathrm{t}-1}^{*}$ & $\begin{array}{l}0.416^{* * * *} \\
(0.091)\end{array}$ & $\begin{array}{c}0.091 * \\
(0.049)\end{array}$ & $\begin{array}{l}-0.004 \\
(1.618)\end{array}$ \\
\hline $\mathrm{y}_{\mathrm{t}-2}$ & $\begin{array}{l}0.294 * * * \\
(0.093)\end{array}$ & $\begin{array}{l}0.245 * * * \\
(0.083)\end{array}$ & $\begin{array}{c}0.799 \\
(4.310)\end{array}$ & $\mathrm{y}_{\mathrm{t}-2}^{*}$ & $\begin{array}{c}0.155^{*} \\
(0.092)\end{array}$ & $\begin{array}{c}0.097^{*} \\
(0.049)\end{array}$ & $\begin{array}{c}1.569 \\
(1.629)\end{array}$ \\
\hline $\mathrm{p}_{\mathrm{t}-1}$ & $\begin{array}{l}0.510 \text { *** } \\
(0.090)\end{array}$ & $\begin{array}{l}0.415 * * * \\
(0.081)\end{array}$ & $\begin{array}{l}-9.022 * * \\
(4.179)\end{array}$ & $\mathrm{p}_{\mathrm{t}-1}^{*}$ & $\begin{array}{c}0.109 \\
(0.185)\end{array}$ & $\begin{array}{l}0.944 * * * \\
(0.099)\end{array}$ & $\begin{array}{c}2.903 \\
(3.280)\end{array}$ \\
\hline $\mathrm{p}_{\mathrm{t}-2}$ & $\begin{array}{l}-0.268 * * * \\
(0.098)\end{array}$ & $\begin{array}{l}-0.520 * * * \\
(0.088)\end{array}$ & $\begin{array}{c}6.635 \\
(4.552)\end{array}$ & $\mathrm{p}_{\mathrm{t}-2}^{*}$ & $\begin{array}{l}-0.204 \\
(0.182)\end{array}$ & $\begin{array}{l}-0.279 * * \\
(0.098)\end{array}$ & $\begin{array}{l}-0.517 \\
(3.234)\end{array}$ \\
\hline $\mathrm{u}_{\mathrm{t}-1}$ & $\begin{array}{c}0.002 \\
(0.002)\end{array}$ & $\begin{array}{l}-0.006 * * * \\
(0.002)\end{array}$ & $\begin{array}{l}0.797 * * * \\
(0.106)\end{array}$ & $\mathrm{u}_{\mathrm{t}-1}^{*}$ & $\begin{array}{l}-0.004 \\
(0.006)\end{array}$ & $\begin{array}{c}0.005^{*} \\
(0.003)\end{array}$ & $\begin{array}{c}1.138 * * * \\
(0.098)\end{array}$ \\
\hline $\mathrm{u}_{\mathrm{t}-2}$ & $\begin{array}{l}-0.002 \\
(0.002)\end{array}$ & $\begin{array}{l}0.007 * * * \\
(0.002)\end{array}$ & $\begin{array}{l}-0.086 \\
(0.102)\end{array}$ & $\mathrm{u}_{\mathrm{t}-2}^{*}$ & $\begin{array}{c}0.008 \\
(0.005)\end{array}$ & $\begin{array}{l}-0.002 \\
(0.003)\end{array}$ & $\begin{array}{c}-0.284 * * \\
(0.096)\end{array}$ \\
\hline $\mathrm{m}^{\mathrm{s}}$ & $\begin{array}{l}-0.036 \\
(0.066)\end{array}$ & $\begin{array}{l}0.253 * * * \\
(0.059)\end{array}$ & $\begin{array}{l}-2.676 \\
(3.072)\end{array}$ & $\mathrm{m}^{\mathrm{s}^{*}}$ & $\begin{array}{l}0.094 * * * \\
(0.032)\end{array}$ & $\begin{array}{c}0.004 \\
(0.017)\end{array}$ & $\begin{array}{l}-0.853 \\
(0.560)\end{array}$ \\
\hline$i^{*}$ OND & $\begin{array}{c}0.001 \\
(0.001)\end{array}$ & $\begin{array}{l}-0.004 * * * \\
(0.001)\end{array}$ & $\begin{array}{l}-0.047 \\
(0.067)\end{array}$ & $i^{*}$ OND & $\begin{array}{l}0.005 * * * \\
(0.002)\end{array}$ & $\begin{array}{c}0.001 \\
(0.001)\end{array}$ & $\begin{array}{c}-0.082 * * \\
(0.030)\end{array}$ \\
\hline$g$ & $\begin{array}{l}0.060 * * \\
(0.029)\end{array}$ & $\begin{array}{l}-0.035 \\
(0.026)\end{array}$ & $\begin{array}{c}0.566 \\
(1.335)\end{array}$ & $\mathrm{g}^{*}$ & $\begin{array}{l}0.320 * * * \\
(0.055)\end{array}$ & $\begin{array}{l}-0.002 \\
(0.029)\end{array}$ & $\begin{array}{l}-1.837^{*} \\
(0.970)\end{array}$ \\
\hline $\mathrm{R}^{2}$ & 0.998 & 0.993 & 0.900 & $\mathrm{R}^{2}$ & 0.999 & 0.998 & 0.986 \\
\hline SEE & 0.007 & 0.007 & 0.343 & SEE & 0.005 & 0.002 & 0.081 \\
\hline $\mathrm{F}$ & 6045.920 & 1417.100 & 87.370 & $\mathrm{~F}$ & 7648.320 & 7461.580 & 812.570 \\
\hline $\mathrm{N}$ & 97.000 & 97.000 & 97.000 & $\mathrm{~N}$ & 112.000 & 112.000 & 112.000 \\
\hline
\end{tabular}

Note: Table 1 and 2a. y: ln of gross domestic product, p: ln of CPI, w: ln of wages, ce: $\ln$ of compensation of employees, e+p*-p: ln of TOT, $\mathrm{p}_{\text {oil }}:$ In of price of oil, u: Unemployment rate, ***: Significant at the $1 \%$ level, **: Significant at the 5\% level and *: Significant at the $10 \%$ level. Source: Table 1.

In EMU, $\mathrm{M}^{* \mathrm{~s}}, \mathrm{i}^{*}$ OND and $\mathrm{g}^{*}$ are affecting positively $\mathrm{Y}^{*}$; no policy instrument has any effect on $\mathrm{P}^{*}$; and $\mathrm{i}^{*}$ OND and $\mathrm{g}^{*}$ have a negative effect on unemployment. Figure 1 and 2 show the impulse responses after a shock on the innovation variable and its transmission to all the other endogenous (objective) variables through the dynamic (lag) structure of the VAR (Table 8). The above results support our hypothesis that the European integration has caused a very high cost to Greece, which exceeds the benefits.

Some socio-political implications of macroeconomic shocks and public policy ineffectiveness: Countries are different in Europe; for this reason their independence and sovereignty is necessary (even though that the pressure they encounter from the globalists is tremendous). Each one nation faces its own idiosyncratic shocks; then, self-sufficiency is necessary, also independent public policies are needed to stabilize the domestic economy and improve the domestic welfare, which depends on the socio-philosophical conditions and value system of the country and not on some value neutral economic and financial indicators imposed by the EMU. We need a continuous improvement in our societies for the benefits of all the citizens, who have dual needs (physical and spiritual).

We assume imperfect capital mobility, here, which means that a rise in domestic (Greek) interest rates above the European rates generates capital inflows, 

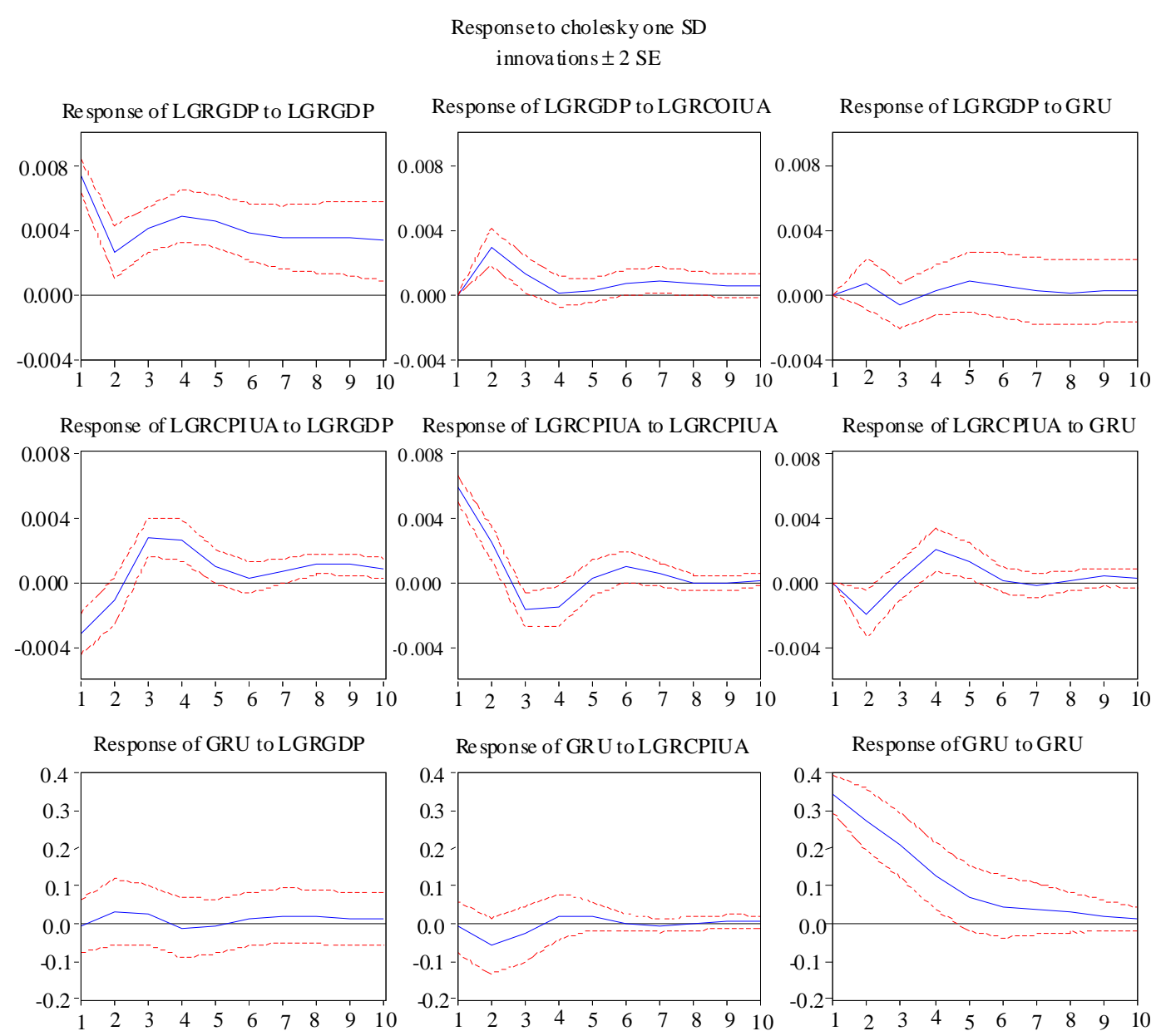

Fig. 1: The impulse responses in Greece. Note: LGRGDP $=\ln$ of Greece's GDP, LGRPIUA $=\ln$ of Greece's price index and GRU = Greece's unemployment rate. Source: Table 8

but not in such massive amounts as it is required with the low return on the European rates. In the context of imperfect capital mobility, the government can attain the goals of internal balance (full employment) and external balance (balanced payments) through the use of a fiscal and monetary policy mix. But, here, the objective of the country cannot be satisfied because the Maastricht criteria put restrictions on the country's variables and domestic public policies are ineffective. Our concern is the determination of output (and employment), prices (inflation), interest rates, current account balance and other variables in these two economies (Greece and EMU) operating under a common flexible exchange rate. We are particularly interested in the problem of EMU suffering from unemployment and of Greece from high interest rates and current account deficits, national debt, unemployment and lost of her sovereignty. Their national, business and households debts are very high in both entities, which have disastrous personal and social effects currently, due to the financial crisis and the recession and might have catastrophic consequences effects in the future on both economies.

In a world of managed (dirty) floating exchange rates, the Central Banks intervene from time to time in foreign exchange markets, which will affect the international reserve holdings of central banks (Fed, Bank of England, Bank of Japan, Swiss Central Bank and ECB). Many times, they do not allow the exchange rate to adjust to guarantee external payments balance. Then, the economy's international transactions carried out and recorded by the Current Account (CA) and Capital Account (KA) are not balanced to zero, but an official reserve settlements account (OS) requires to make the Balance of Payments (BP) zero:

$\mathrm{BP}=\mathrm{CA}+\mathrm{KA}+\mathrm{OS}=0$ 

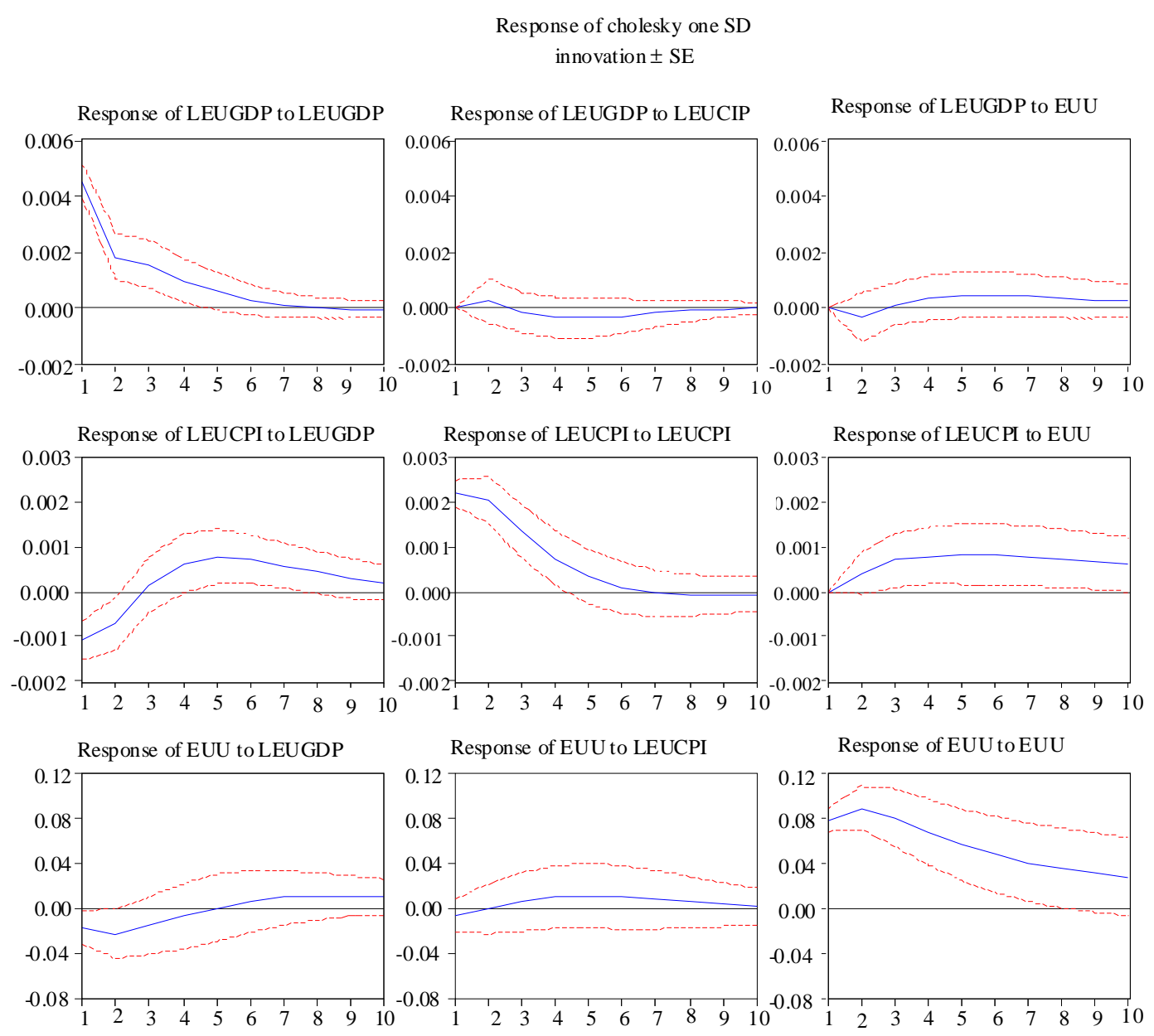

Fig. 2: The impulse responses in the EMU. Note: LEUGDP $=\ln$ of EMU GDP, LEUCPI $=\ln$ of Euro-zone consumer price index and EUU $=$ Euro-zone unemployment rate. Source: Table 8

The central banks' holdings of international reserves are influenced by the international transactions of domestic and foreign residents. At a given level of the exchange rate $(\mathrm{E})$ and in the absence of any disturbances affecting autonomous spending, Eq. 6 and 2 provide us with the combinations of domestic prices (p) and incomes $(\mathrm{Y})$ that create equilibrium in the aggregate economies $(\mathrm{AD}=\mathrm{AS})$. These are the $\mathrm{AD}$ and $\mathrm{AS}$ curves. A rise in the nominal money supply increases real money balances, at a given level of the price of domestic goods. As domestic interest rates decline, investment and aggregate demand for domestic goods increase, at a given level of price and shifts the $\mathrm{AD}$ schedule to the right. This increase in $\mathrm{AD}$ will affect the prices gradually. As the price of domestic goods increases, employment will also tend to rise over the short run. The result is an increase in output. As prices rise, employment increases, because real wage is declining.
Changes in the nominal money supply induce shifts of the AD curve. An open market purchase will clearly increase the money supply and at a given price level, the resulting increase in real money balances would then place downward pressure on domestic interest rates, inducing capital to flow out of the economy and depreciating domestic currency. Unfortunately, Greece has lost her policy tool and the entire economy will suffer, until she will go back to drachma. Then, the consequence would be an expenditure switch out of foreign and into domestic goods, with a resulting increase in spending on domestic goods. This corresponds to a shift of the AD curve to the right. An expansion of demand for domestic goods and services has become necessary for small EMU economies, which have high unemployment and foreign trade deficits.

This short-run output boom induced by the increase in the money supply is closely linked to the decline in 
real labor costs associated with this disturbance. With nominal wage rates rigid over the short-run, the inflationary spur associated with the monetary expansion will reduce real wage rates. These reduced real labor costs and the consequent stimulus to domestic production have, as a counter part, a greater competitiveness of domestic goods in international markets, which is reflected in an increased real exchange rate. Of course, the labor cost has declined in Greece, due to illegal migration, pressure from the ECOFIN and the current deep recession.

In conclusion, the short-run expansionary impact of the monetary disturbance is closely linked to the decline of real wages, which spearheads an increase in net exports. Then, an expansion of the money supply will tend to shift the aggregate demand curve upward. By increasing the money supply, policy makers could, in principle, move the economy to full employment. It speeds it up by igniting inflation and therefore reducing real wages in the short-run. A domestic monetary expansion leading to increases in nominal and real exchange rates (currency depreciation) raises $\mathrm{AD}$ by improving the trade balance. But, members of EMU cannot have these benefits. At the same time, this policy implies that the foreign countries whose currencies appreciate both in nominal and real terms will face deteriorating net exports and a contraction of $\mathrm{AD}$. Expansionary domestic monetary policy raises domestic real income-albeit, if temporarily at the expense of a reduction in real income abroad. Then, international policy conflicts arise from currency-depreciating policies under flexible exchange rates. These public policies effects have been lost for the EMU members, because of their common currency (euro) since January 1, 2002. On the other hand, the US has benefited from the depreciated dollar the last 6 years.

The aggregate demand curve is derived on the basis of a given level of the money supply, price level, the exchange rate, the TOT, aggregate spending, foreign income and fiscal policy parameters. Changes in any of these variables will tend to shift the AD curve. Also, any expansionary fiscal (monetary) policy has a positive multiplier effect on the AD for domestic goods, at any given level of prices shifting the AD curve to the right. Further, any increase in foreign income has a positive effect on our $\mathrm{AD}$, depending on the foreign income elasticity of their demand for imports. Finally, a country must produce all goods and services that its citizens need, otherwise it has to become a net importer and a continuing borrower from abroad. Public policies are facing restrictions from ECB and ECOFIN and their effects on AD are very limited.
There is no question that public policies are playing a major role in our economies and affect the real macro-variables and our lives. Now, due to recession and low personal income, AD is very weak. On the other side, we have the production of a nation, the Aggregate Supply (AS). The interaction of AS and $\mathrm{AD}$ determines the equilibrium level of output (real income) and prices in the economy. The aggregate supply is derived on the basis of given wages, TOT, price of oil, exchange rate and unemployment rate. As the price of domestic goods increases, employment will also tend to rise over the short run. The result is an increase in output. This positive relationship between changes in prices and quantity supplied of domestic goods in the short run is the short run AS curve of domestic goods. As prices rise, employment increases because real wage is declining, then the output increases.

The economy is in short run equilibrium when the quantity demanded of domestic goods equals the quantity supplied of domestic goods. There is a simultaneous short run equilibrium in the goods, money and labor markets. But a broad array of situations can destabilize an economy, leading it to either, balance of payments difficulties, national debts, recessions and high unemployment (as it is in Greece and the EU for the last years), accelerated price increases (inflation) or to all of them combined. An external shock in the form of increased raw material and energy prices (as it happened before, where the price of oil rose in one year from $\$ 11.38$ to $\$ 29.88$ per barrel; during summer 2008 , its price surpassed $\$ 145.00$, then, it fell in December of 2008 to $\$ 33.87$ and today, June 1, 2009 it is $\$ 67.82$ per barrel) have raised the costs of imported inputs, inducing the AS curve to shift to the left, causing domestic prices to rise and output to fall and trade deficits to deteriorate. Internal events in the economy may also contribute to destabilization, i.e., an increase in taxes, which will shift the economy's AS leftward, increasing domestic prices, deteriorating the economy's international competitiveness, worsening its trade balance and reducing its national product because multinational firms are moving to lower cost countries. Increased government spending could have a permanent positive effect on output if the economy is below full employment, but at the same time, it will be inflationary if not combined with measures such as tax cuts, that shift aggregate supply. Financial market volatility (risk), due to deregulation and corruption, has caused the worst problems in our economic history. Currently, the housing market and the automobile industry have created serious problems in the EU's, Greece's and the US's growth. 
The long run equilibrium of an economy occurs at that point where there is full employment and balanced payments. Today, almost all countries are in disequilibrium because they face unemployment (deep recessions) and deficits in their balance of payments accounts. The free-market economy is acting procyclically and without governments' and central banks' interventions and regulations (controls), the economies will be in long-run disequilibria for a very long time. But, these two institutions are becoming less and less effective, daily ${ }^{[10]}$. Macroeconomic adjustment programs are intended to speed up the adjustment of an economy toward long-run equilibrium. Policies must be enacted in situations, in which the economy is not characterized by full employment and price stability, but is instead suffering initially from high unemployment, chronic inflation, trade account deficit, national debt, as the latest crisis. A wide range of disturbances can destabilize an economy, leading it to stagnation, unemployment, inflation, deficits or to all these problems combined, because we allow this freemarket to be completely free from any regulations, which has negative effects on human beings freedoms and their welfare.

An expansion of government spending $(G)$ raises aggregate demand for domestic goods, (but the government is buying from abroad and thus, there is no effect on the domestic AD); then, this would shift the AD curve upward. This results in upward pressure on domestic interest rates, generating incipient capital inflows as investors shift their portfolios toward the relatively more attractive domestic assets. The government will supply more securities to finance this new budget deficit. This will appreciate the euro and will induce a switch of aggregate demand out of domestic goods and into more imports, deteriorating the current account and shifting a little to the left the AD curve. But, this increase in aggregate demand might increase income (from $\mathrm{Y}_{0}$ towards $\mathrm{Y}_{\mathrm{F}}$ ). The high income raises money demand and interest rate rises. This increase in income has no lasting effect. Of course, the central bank (ECB) has an interest rate target and will expand the money supply to keep the interest rate on target. Greece is a small economy and her domestic conditions do not affect the EMU. This will shift the $\mathrm{AD}$ curve to the right. As a result of the downward pressure on domestic interest rates, the economy would face massive capital outflows as investors switch toward the relatively more attractive foreign assets. The results will not affect the euro. This in turn, will not shift aggregate demand toward domestic goods and production will not increase. Then, this expansionary fiscal and tight monetary policy have increased interest rate, deteriorated the budget deficit, but does not increase output (unemployment has not decline), does not depreciate the currency and cannot improve the current account.

Within the context of imperfect capital mobility, the government can attain the goals of internal balance (full employment) and external balance (balanced payments) through the use of monetary and fiscal policies. But, these public policies have been lost for the EMU country members; they have become exclusive policies of the ECB and of the European Commission. The countries in Euro-zone have lost their exchange rate policies (devaluation of their currencies) and the free trade agreements with the rest of the world do not allow them to use any protective trade policies (tariffs, quotas, qualitative restrictions). Also, from 2003 to 2008, we had an unexpected appreciation of the euro, which has affected Greece's and EU's exports negatively, but prices in Euro-area have not decline, they have increased absurdly, which show that free market does not work, there, so the euro and the entire Economic and Monetary Union was not a very good and thoughtful choice.

The data show that Greece is not close to full employment (the gap was small, which means that the country was relatively close to this point of production, however since 2007 the growth of the real output is very small and is going towards negative growth; unfortunately, she will not avoid a deep recession), but EMU is far away to the left of full employment (all member-economies are experienced high unemployment and recessions). If the equilibrium of the economy lies to the left of this vertical segment of the AS line, it faces unemployment. The desired point in terms of the government's and central bank's goals is at full employment, where both internal and external balances are obtained. An appropriate combination of fiscal and monetary policies is necessary to attain internal and external balance. Trade balance equilibrium requires an expenditure-switching policy from foreign to domestic goods and an optimal interest rate $^{[21]}$ to affect positively the capital account balance and the domestic economy.

The empirical results show that Greece has become riskier (has higher social losses) after the 1981 integration with the EU and during 2001 (joining the EMU). Her high unemployment has been caused from increases of European exports to Greece and from the high ECB overnight rate; also, from illegal migration with the abandonment of her borders' control (due to integration). Her public policies are ineffective (especially on employment). Then, the cost of integration exceeds its benefits, which proves our 
hypothesis, too. These results are different from previous research, which was optimistic about the future benefits of European integration on its memberstates by ignoring social and country-specific factors. More individual country-members analysis is needed to compare the different effects of EU integration on its members (old and new, rich and poor ones).

Finally, economic liberals claim that society is better off when allocation is done by the "dirty" speculators in the "free-markets", who are in conflict with the public policies, rather than by the exercise of mixed powers (political, social, economic, ethical, cultural and traditional and others) to all citizens and markets. The negative results of globalization are already obvious from now to the entire world. Sovereign nations must undertake actions, which can be justified either on efficiency grounds, on equity grounds and on cultural peculiarities. The utilities of the citizens are interdependent and the social welfare function incorporates an ethical valuation of all citizens' individual utility functions. Leaders and scientists are responsible to determine the welfare-maximizing state (the "point of bliss", a state of perfection) for the entire society. We cannot provoke or scandalize or underrate any person in our society.

\section{CONCLUSION}

The economic and social indicators reveal that Greece from a moral, ethical, just, independent and self-sufficient traditional society, after her European integration is becoming less and less competitive and more and more contaminated from all these foreign influences; and EU is becoming less friendly with its members (especially the small ones) and the rest of the world. European Union (the forced integration of 27 nations, without referenda) is the worst "innovation" in human history. It is a mixture of twenty seven nations without domestic public policies, without selfdetermination, without sovereignty and of course, without any future. All these strange evolutions have increase the global uncertainty, have caused unemployment and recessions in EU and in Greece, have reduced competitiveness and have augment anxiety and health problems (mental and physical) to citizens. The free-market system has failed and needs more government regulation and better corporate governance. The government had to bailout a corrupted financial system, especially when the federal deficit and the national debt are astronomical. But, it had no other option, except to "rob responsible [citizens] and pay the robbers of the financial market". Then, what are the social benefits? Why we need these global changes and "evolutions", which are against humanity? What are the social benefits of the European Union and the EMU?

The data and the "News" show that the uncertainty is tremendous and is growing. The western economies are losing competitiveness and the unemployment in Europe and in Greece, as part of the EU, is holding steadily (in some regions, like Epirus, it is $40 \%$ ). The US economy is doing better than the European, but the euro is doing much better than the dollar. Paradox! The current world is a big paradox, so we are not surprised any more. The Greek income is affected by prices, wages, TOT (real exchange rate), price of oil and unemployment. Likewise, it is affected by the money supply, consumption, exports, imports and EMU income. The Greek unemployment is caused by production, compensation of employees and money supply. Also, it is caused by EMU prices, European wages, money supply of the ECB, European consumption, overnight deposit rate and European exports. Besides, a tremendous interdependence exists between Greece and the European economy. We see that the US and the EU financial markets rise and fall together (due to globalization), but trade and FDI influence the movement of real economic variables, such as output, prices and unemployment. The Greek and EMU economies move very close and a demand shock in the one ripples through the other via imports and exports, as correlation coefficients and causality tests are shown. Monetary policy $\left(\mathrm{M}^{\mathrm{s}}\right.$ and $\left.\mathrm{i}^{*} \mathrm{OND}\right)$ is affecting prices and fiscal policy $(G)$ is improving production. Unfortunately, public policy has no effect on employment.

In brief, the European economies that copy the US, have two major problems; overconsumption (underproduction and waste of resources) and lack of savings (dis-saving and borrowing or spendthrift) ${ }^{[14]}$. These cause current account deficits and capital account surpluses, which affect the financial markets, the interest rates, the national debt, the oil prices and the inflation. We must learn that we cannot live beyond our means indefinitely, as individuals and nations. Actually, there is a vicious cycle in the economy. Without an investment in sustainable development, EU will lose the competitiveness race. The Chinese "invasion" is a serious threat for Europe. The global uncertainty, the illegal migration and the other domestic problems, due to globalization and integration are going to change our economic system (many economic laws do not hold anymore) to "glob-onomics" or "shock-onomics". The only prediction that we can do for the future, after the current financial crisis and the deep recession, is that this new economic system will be the last in our socioeconomic history, except if we will decide to go back to 
a value oriented system. These corrupted people in financial markets needs some knowledge in valueoriented welfare economics and business ethics.

What we have discussed here illustrates the inherent difficulties of attaining multiple objectives in an open economy today with the globalization and especially if these economies are members of the same economic and monetary union. Contractionary monetary and fiscal policies oriented toward a rapid improvement in the balance of payments will generate a sharp recession and increased unemployment. Alternatively, if a devaluation is used to attain balanced payments and to raise output, prices will rapidly increase, fueling inflation. Finally, if contractionary demand policies are attached to devaluation as a package, price stability and balanced payments can in principle be attained, but unemployment will not be completely eliminated. The main reason for these conflicts of objectives lies in that, with an unchanged aggregate supply curve, the range of possible equilibria of the economy will lie along the curve, implying a short-run trade off between output and price increases. This suggests that policies oriented toward increasing aggregate supply (shifting the AS curve to the right) may have an important role in macroeconomic adjustment programs. This type of approach was popularized in early 1980s by so-called "supply side economics", whose emphasis was on the use of tax cuts, labor market incentive policies and other policies intended to manipulate aggregate supply ${ }^{[37]}$. But, today, the problem is not $\mathrm{AS}$, but $\mathrm{AD}$, due to low income and high unemployment.

The character of political, economic and monetary unions is deeply influenced and depend on the density of associational life in the union, the level of social trust, the confidence towards the free-market system, the education, the language, the history, the culture, the tradition, the religion and a variety of other sociocultural factors that lead countries and individuals into closer social relations within the union. Now, on matters of policy [the future of the Common Agricultural Policy (CAP), the Union's external trade relations, co-operation on defense, enlargement, the Euro-constitution (= Treaty of Lisbon)] the voices of the small nations must be heard. Further ambitions for European integration need to be balanced by an understanding of the gains and loses (cost-benefits analysis) that countries has had from the European projects. Security is also a serious issue and especially for Greece. Trade with the US and the rest of the world (China) is another major problem together with inward investment, high unemployment, foreclosures in the housing market and to promote healthy competition rather than oligopolies and monopolies, as at present. People must be encouraged to save instead of borrowing, over-consuming and wasting their resources. High savings rate is necessary for Greece that she can support the domestic needs for investment.

The first thing that will be missing from EU and its country-members, are the unique historical circumstances of the years between 1945 and 1989, which cannot be reproduced. The world is moving towards a new era; the century of delusion, of rebellion, of corruption, of powerful, of slavery, of uncertainty, of planned financial crises and of destruction. The disruptive effect of the decline of the Soviet Union has been at least as great in the East as in the West, due to the loss of balance between them. Germany, on the other hand, after the unification has become once again the great power of Europe leaving far behind France and the others. The current financial crisis has a negative effect on every economy because of globalization. Independence and self-sufficiency is better than any of today's submissions. The elections for the European parliament on June 7, 2009, showed the opposition of the Europeans towards their political system. The overall turnout was only $42.94 \%$ and in Greece $52.63 \%$; the rest of the EU population chose to go swimming instead of voting.

In summary, we (especially Greeks) must be aware that we are undergoing changes in our financial, economic, geopolitical, cultural and risk contexts and we must be sensitive and act with attention to these changes. Russia is not an enemy of the west, west is actually an enemy for Russia and the rest of the world; and Asia may be proven to be a future "enemy" for the entire west, the EU and the US. We cannot be opportunists and we cannot be danger-speakers, but realists, altruists, humanists and truthful. "From the start, the construction of Europe was an extravagant political idea designed to imprison the nations of Europe into an 'ever closer' union of states" ${ }^{\text {"[5] }}$, as Serfaty ${ }^{[57]}$ has said. The best will be to reassess the need to move forward with the union or to hold back. Holding back might preserve whatever remains of each state's sovereignty and culture. We do not need any type of integrations and of course we do not want to have a supra-nationality as a minority of people believes, but it has louder voice, powerful control and global influence than the majority. In recent years, citizens of Europe and of the US have shown their disappointment in and apprehensions for whom to vote. They try to elect the least evil in their questionable and immoral "democracies". The elected representatives are unable to act in favor of their countries' interest. Their corruptive practices have become a national way of life. 
In EU there are different Europeanized domestic parties that all have the same beliefs and objectives, to ignore their countries; and they have created a class of citizens through favoritism and job offering to them that these voters support and fight for these parties. Territorial changes and political upheavals, as well as a public sense of lost identity and a public loss of faith in the government and all their leaders have become citizens' every day problems. Euro-communism is doing relatively better in EU (and in Greece is terrorizing businesses and universities) than in Russia, now. All these can have a profound negative effect on individual country-members and on the current interdependence between the EU and its members. But, the current problem is to recover from the financial crisis and its recession, which seems as a very long process.

Finally, even though that international economic co-operation is necessary today than ever, it is no need for economic integrations. As interdependence and complexity of the economies have increased, the existing instruments of co-operation have become less and less able to avoid or resolve the conflicts between countries' different policies. In the monetary field, there was a time when fixed exchange rates were universally accepted as the norm and the dollar as the international currency; both these key elements have been abandoned and nothing so far has taken their place. In the commercial field, the geographical area, which was significant for GATT (WTO now) has grown wider than institutions' geographical sphere of influence; in addition, it is almost powerless to deal with a number of trade conflicts concerning powerful countries. In the area of macro-policies, the west infrastructure represented by the common acceptance of the Keynesian paradigm as a basis for co-operative efforts has been lost and some new neo-liberal policy objectives, doctrines, ideologies and corruption have created enormous conflicts among nations. In the area of capital movements, a fully fledged, largely uncontrolled, extremely speculative international financial system has superseded segmented national markets and has increased bankruptcies, loss of properties (houses) and assets (which have been used as collateral) and loss of wealth and many other redistributions of wealth from low income and poor to richer people. In another important area that of labor mobility, an uncontrolled, unregulated, satisfied political expediencies illegal migration has caused serious employment, safety, crime, security and population balance problems. This illegal labor is the number one problem in EU and in Greece, right now. The last most important area is national security ${ }^{[44]}$ and international peace objective; there are no international institutions or international laws or international community, which can intervene and find a political, economic and social solution to the current mounting problems. The governments and international organizations have lost control and powers outside them (multinational businesses, markets) are doing what ever they like to satisfy their self-interest (profit) acting against the social well-being. The glob has become a large risky jungle; but, the worst for Greece is that the benefits of EU and EMU are far less than the tremendous costs of this "prototype" of globalization. The remedy is: Greece will be better off to opt out from the Euro-zone and to go back to drachma, to her domestic public policy, to her independence, to her sovereignty.

\section{REFERENCES}

1. Basu, P., S. Ghosh and I. Kallianiotis, 2001. Interest rate risk, labor supply and unemployment. Econ. $\quad$ Model., 18 : 223-231. http://ideas.repec.org/a/eee/ecmode/v18y2001i2p2 23-231.html

2. Dickey, D. and W.A. Fuller, 1979. Distribution of the estimates for autoregressive time series with a unit root. J. Am. Stat. Assoc., 74: 427-431. http://www.jstor.org/pss/2286348

3. Engle, Robert F. and C.W.J. Granger, 1987. Cointegration and error correction: Representation, estimation and testing. Econometrica, 55: 251-276. http://ideas.repec.org/a/ecm/emetrp/v55y1987i2p2 51-76.html

4. Granger, C.W. J., 1969. Investigating causal relations by econometric models and cross-spectral methods. Econometrica, 37: 424-438. http://ideas.repec.org/a/ecm/emetrp/v37y1969i3p4 24-38.html

5. Granger, Clive and P. Newbold, 1974. Spurious regressions in econometrics. J. Econometr., 2: 111-120. http://ideas.repec.org/a/eee/econom/v2y1974i2p11 1-120.html

6. Hicks, J.R., 1937. Mr. Keynes and the 'Classics'; a suggested interpretation. Econometrica, 5: 147-159. http://stevereads.com/papers_to_read/keynes_and_t he_classics.pdf

7. Johansen, S., 1991. Estimation and hypothesis testing of cointegration vectors in Gaussian vector autoregressive models. Econometrica, 59: 1551-1580. http://www.jstor.org/stable/2938278

8. Johansen, Soren and Katarina Juselius, 1990. Maximum likelihood estimation and inferences on cointegration-with applications to the demand for money. Oxford Bull. Econ. Stat., 52: 169-210. http://ideas.repec.org/a/bla/obuest/v52y1990i2p169 $-210 . \mathrm{html}$ 
9. Kallianiotis, I.N., 2009. The three socio-economic troubles of the free-market: Uncertainty, unemployment, untrustworthiness. Unpublished Manuscript, November, University of Scranton, pp: 131.

10. Kallianiotis, I.N., 2009. European privatization and its effects on financial markets and the economy from a social welfare perspective. International Research Journal of Finance and Economics, 28: 66-85. http://eurojournals.com/finance.htm

11. Kallianiotis, I.N., 2008. The three socio-economic miseries: Global uncertainty, European unemployment and the waning american capitalistic games. Unpublished Manuscript, October, University of Scranton, pp: 76.

12. Kallianiotis and I.N., 2008. Global Uncertainty, european unemployment and the waning american competitive games. Unpublished Manuscript, March, University of Scranton, pp: 47.

13. Kallianiotis and I.N., 2007. Economic fundamentals, expediency, or naïve speculation caused the Euro's overvaluation. Unpublished Manuscript, November, University of Scranton, pp: 44.

14. Kallianiotis I.N., 2007. Macroeconomic shocks and public policy effectiveness in open economies: USA and European Union. Proceedings of the NBEA, Central Connecticut State University Conference, Nov. 8-9, New Britain, CT., pp: 164-167.

15. Kallianiotis I.N., 2007. Europe: A Swift historical journey from the ancient times to the current European Union. Unpublished Manuscript, December, University of Scranton, pp: 104.

16. Kallianiotis, I.N., 2005. Public policy effectiveness, risk and integration in the western economies. J. Am. Acad. Bus., Cambridge, 6: 170-178. http://www.jaabc.com/jaabcv6n1 preview.html

17. Kallianiotis, I.N., 2004. European Union: Interest rate risk and its effect on unemployment. Ind. J. Econ. Bus., 3: 31-45. http://www.ijeb.com/Year2004_June.htm

18. Kallianiotis, I.N., 2003. European Union and United States: Economic fundamentals, interest rate risk and their effect on unemployment. Unpublished Manuscript, February, University of Scranton, pp: 27.

19. Kallianiotis I.N., 2003. American business objective: An alternative approach. J. Am. Acad. Bus., Cambridge, 3: 197-204. http://www.jaabc.com/jaabcv3n3preview.html

20. Kallianiotis I.N., 2003. Corporate firm objective, valuation and risk: A new revisional frontier of finance. Unpublished Manuscript, May, University of Scranton, pp: 20.
21. Kallianiotis, I.N., 2002. Recent developments in European Union. Unpublished Manuscript, February, University of Scranton, pp: 60.

22. Kallianiotis I.N., 2001. European Interdependence and economic integration: A kalman filtering model. J. Bus. Econ. Stud., 7: 68-91. http://connection.ebscohost.com/content/article/10 19443716.html;jsessionid=4F5D6EB73909B45087 D363B36E949755.ehctc1

23. Kallianiotis, I.N., 2000. Factor-mobility, interdependence and integration, but still factorprice disequalization in European Union. J. Bus. Soc., 13: 5-28.

24. Kallianiotis, I.N., 1996. Balance of payments, economic linkages and financial interdependence among countries: US and EU. Unpublished Manuscript, October, University of Scranton, pp: 54.

25. Kallianiotis I.N., 1996. European integration and economic interdependence among countries: The US and the EU. Unpublished Manuscript, December, University of Scranton, pp: 133.

26. Kallianiotis I.N., 1996. Interdependence among economies: USA and EU-countries. Unpublished Manuscript, University of Scranton, pp: 33.

27. Kallianiotis, I.N. and A. Boutchev, 1996. The United States economy and its transmission mechanism to European Union. Unpublished Manuscript, September, University of Scranton, pp: 32.

28. Kallianiotis, I.N. and S. Cheruvathoor, 1997. Public Investment, productivity growth and employment in the United States and the European Union. Unpublished Manuscript, February, University of Scranton, pp: 20.

29. Kallianiotis, I.N. and I. Petsas, 2009. Interdependence between US and EU goods, money and foreign markets and spillover effects. Pennsylvania Econ. Rev., 16: 88-122. http://aux.edinboro.edu/pea/pub/review.html

30. Kallianiotis, I.N. and I. Petsas, 2006. Public policy effectiveness on a loss to society function and inflation dynamics. Spoudai, 56: 7-43. http://www.unipi.gr/eng_site/akad_tmhm/oikon_ep ist/oikon_epist_spoudai_odhgies.html

31. Kallianiotis, I.N. and I. Petsas, 2005. Unemployment, inflation and public policy in a growth model. Proceedings of the NEDSI 2005 Conference, Mar. 30-Apr. 1, Philadelphia.

32. Meyer and H. Laurence, 2001. Inflation targets and inflation targeting. Review. Federal Reserve Bank of St. Louis, 83: 1-13. http://findarticles.com/p/articles/mi_hb4356/ 
33. Phillips, P. and P. Perron, 1988. Testing for a unit root in time series regression. Biometrica, 75: 335-346. http://biomet.oxfordjournals.org/cgi/content/abstra ct/75/2/335

34. Vasiliades, Nikolaos P., 1993. Agios Markos o Eugenikos kai I Enosis ton Ekklision. SOTIR Publishers, Athens, Greece.

35. Blum, Jerome, R. Cameron and Thomas G. Barnes, 1970. The European World: A History. 2nd Edn., Little, Brown and Company, Boston, USA. http://www.questia.com/library/book/theeuropean-world-a-history-by-thomas-g-barnesjerome-blum-rondo-cameron.jsp?

36. Bryant, R.C., D.W. Henderson, G. Holtham, P. Hooper and S.A. Symansky 1988. Empirical Macroeconomics for Interdependent Economies. The Brookings Institution, Washington, DC., ISBN: 10: 0815711409, pp: 342.

37. Canto, V., D. Joines and A. Laffer, 1983. Foundations of Supply-Side Economics. Academic Press, Inc., New York, ISBN: 10: 0121588203, pp: 283.

38. Chomsky N., 2004. Hegemony or Survival: America's Quest for Global Dominance. Henry Holt and Company, New York, USA., http://www.democracynow.org/2003/10/22/noam_ chomsky_on_hegemony_or_survival

39. Davies N., 1998. Europe: A History, Harper Perennial, New York, USA. ISBN: 10: 0060974680, pp: 1392.

40. Dornbusch, R., 1980. Open Economy Macroeconomics. Basic Books, New York. ISBN: 0-465-05286-X, pp. 293.

41. Enders, W., 1994. Applied Econometric Time Series. John Wiley and Sons, Inc., New York, USA., ISBN: 10: 0471039411, pp: 448.

42. Hill, B., 1998. The European Union. 3rd Edn., Heinemann Educational Publishers, Oxford, England.

43. Johansen, S., 1995. Likelihood-Based Inference in Cointegrated Vector Autoregressive Models. Oxford University Press, Oxford, ISBN: 0198774508, pp: 267.

44. Kallianiotis and I.N., 1992. Hellas: A Swift Historical Journey and the Macedonian Question. Hellenic Orthodox Church of the Annunciation, Scranton, PA., USA., pp: 64.

45. Keynes, J.M., 1936. The General Theory of Employment, Interest and Money. MacMillan, London. http://www.marxists.org/reference/subject/economi cs/keynes/general-theory/

46. Kokkinakis, D., 2007. Poioi Dolofonisan Ton Kapodistria? Vol. A and B, SIMMETRIA Publishers, Athens, Greece.
47. Moussis, N., 2003. Guide to European Policies. 9th Edn., European Study Service, Belgium. ISBN: 2930119-34-9, pp. 472.

48. Rivera-Batiz, F.L. and L. Rivera-Batiz, 1985. International Finance and Open Economy Macroeconomics. Macmillan Publishing Co., New York. ISBN: 0-02-401620-9, pp. 581.

49. Roberts, J.M., 1998. The Penguin History of Europe. Penguin Books, London, England, ISBN: 10: 0140265619 , pp: 752.

50. Sargent, T. J., 1979. Macroeconomic Theory. Academic Press, New York, USA. ISBN: 0-12619750-4, pp. 404.

51. Viault, B. S., 1990. Modern European History. 1st Edn., McGraw-Hill, Inc. New York, USA., ISBN: 10: 0070674531, pp: 608.

52. Kallianiotis, I.N., 2001. Financial Markets Integration: Real Interest Rate, Saving and Consumption Paths in the EU. In: International Public Policy and Regionalism at the Turn of the Century, Khosrow Fatemi, (Ed.). Pergamon, an imprint of Elsevier Science, Amsterdam, pp: 234-257.

53. Kallianiotis, I.N., 1998. Global Business and Economic Interdependence between the US and the EU. In: Global Business Restructures Worldwide Industries, Economies and Capital Markets, Edward Flowers, B. (Ed.). pp: 1-24.

54. Kallianiotis, I.N., 1998. European Capital Market Integration: Interest Rates and Other Macrovariables. Proceedings of the Northeast Business and Economics Association 1998 Annual Conference, Oct. 29-30, Bentley College, Waltham, Massachusetts, USA., pp: 58-60.

55. Kallianiotis, I.N., 1991. US Budget Deficit and its Long Run Effect on the Economy. Pennsylvania Economic Association 1991 Proceedings, May 2325, Lehigh University, Bethlehem, PA., pp: 614-628.

56. Roberts Ivor, 1996. The EU White Paper on Growth, Competitiveness and Employment, in The US and the EU. In: Economic Relations in a World of Transition, Norman Levine, (Ed.). University Press of America, Inc., Lanham, Maryland, USA., pp: 203-220.

57. Serfaty, S., 1996. Decisions for Europe Fragile State of the Union, a Union of Fragile States in the US and the EU. In: Economic Relations in a World of Transition, Norman Levine, (Ed.). University Press of America, Inc., Lanham, Maryland, USA., pp: 75-92. www.cdi.org/russia/johnson/2175.html 